Provided for non-commercial research and education use. Not for reproduction, distribution or commercial use.

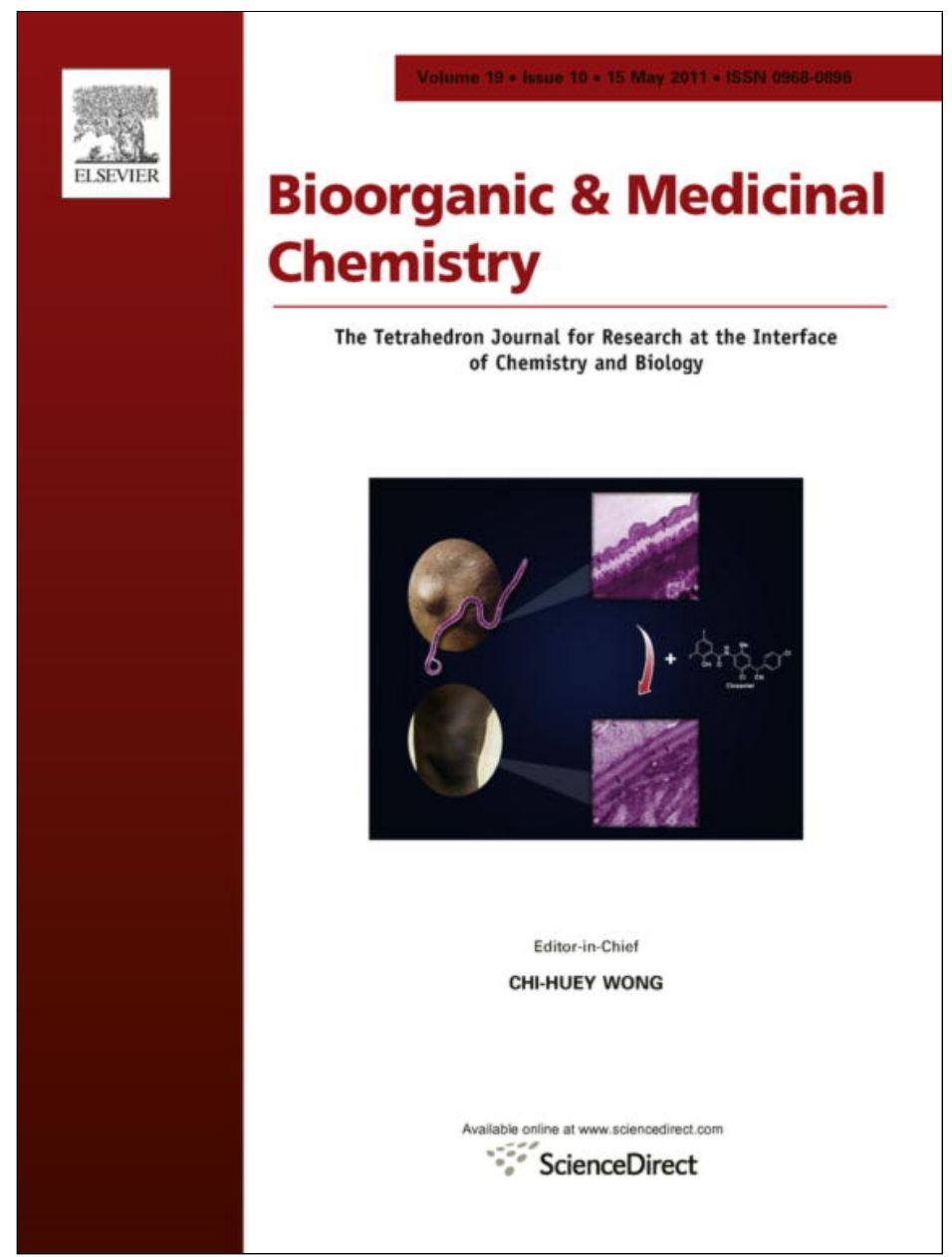

This article appeared in a journal published by Elsevier. The attached copy is furnished to the author for internal non-commercial research and education use, including for instruction at the authors institution and sharing with colleagues.

Other uses, including reproduction and distribution, or selling or licensing copies, or posting to personal, institutional or third party websites are prohibited.

In most cases authors are permitted to post their version of the article (e.g. in Word or Tex form) to their personal website or institutional repository. Authors requiring further information regarding Elsevier's archiving and manuscript policies are encouraged to visit:

http://www.elsevier.com/copyright 


\title{
New 3-, 8-disubstituted pyrazolo[5,1-c][1,2,4]benzotriazines useful for studying the interaction with the HBp-3 area (hydrogen bond point area) in the benzodiazepine site on the $\gamma$-aminobutyric acid type $A\left(G A B A_{A}\right)$ receptor
}

\author{
Gabriella Guerrini ${ }^{\mathrm{a}, *}$, Giovanna Ciciani $^{\mathrm{a}}$, Fabrizio Bruni ${ }^{\mathrm{a}}$, Silvia Selleri ${ }^{\mathrm{a}}$, Fabrizio Melani ${ }^{\mathrm{b}}$, Simona Daniele ${ }^{\mathrm{c}}$, \\ Claudia Martini ${ }^{\mathrm{c}}$, Annarella Costanzo ${ }^{\mathrm{a}}$ \\ ${ }^{a}$ Dipartimento di Scienze Farmaceutiche, Laboratorio di Progettazione, Sintesi e Studio di Eterocicli Biologicamente attivi (HeteroBioLab) Università degli Studi di Firenze, \\ Via U. Schiff, 6, 50019 Polo Scientifico, Sesto Fiorentino-Firenze, Italy \\ ${ }^{\mathrm{b}}$ Dipartimento di Scienze Farmaceutiche, Laboratorio di Molecular Modeling, Cheminformatics and QSAR, Università degli Studi di Firenze, Via U. Schiff, 6, 50019 Polo Scientifico, \\ Sesto Fiorentino-Firenze, Italy \\ ${ }^{\mathrm{c}}$ Dipartimento di Psichiatria, Neurobiologia, Farmacologia e Biotecnologie, Università degli Studi di Pisa, via Bonanno, 6, 56126 Pisa, Italy
}

\section{A R T I C L E I N F O}

\section{Article history:}

Received 20 January 2011

Revised 1 April 2011

Accepted 5 April 2011

Available online 12 April 2011

\section{Keywords:}

Pyrazolo[5,1-c][1,2,4]benzotriazine system

Benzodiazepine binding site

$\mathrm{GABA}_{\mathrm{A}}$-receptors

Ligand-based pharmacophoric model

\begin{abstract}
A B S T R A C T
The pharmacophoric model using ADLR procedure, based on pyrazolo[5,1-c][1,2,4]benzotriazine system, studied in our laboratory, allowed us to identify the essential interaction points ( $\mathrm{HBp}-1, \mathrm{HBp}-2$, and Lp-1) and the important areas for affinity modulation (HBp-3 and $\mathrm{Lp}-2$ ) for binding recognition at benzodiazepine (Bzs) site of $G A B A_{A}$ receptors $\left(G A B A_{A}-R s\right)$. In this work ADLR method is used to rationalize the affinity data of 23 new compounds and to improve the knowledge on HBp-3 area, hydrogen bond area. Among these new compounds emerge the pyrrolo derivatives $(\mathbf{1 8}, \mathbf{2 5}, \mathbf{2 8}, \mathbf{3 4}$, and $\mathbf{3 7})$ for their good affinity value $\left(14.9>K_{\mathrm{i}}(\mathrm{nM})>63.0\right)$. In the orientations proposed by ADLR, the NH moiety of the pyrrole ring, independently of the position in the pyrazolobenzotriazine core, fits in HBp-3 area and points out the acceptor feature of this hydrogen bond area, already known as donor area. Unexpectedly, the oxygen atom of the furane ring does not form efficient hydrogen bond with the same area, probably for an imperfect distance. The size of substituent at position 8 is important but not necessary for the receptor recognition, in fact the interdependence between the features of the 3- and 8-substituent's is again verified, (i.e., compound 20 vs 32).
\end{abstract}

(c) 2011 Elsevier Ltd. All rights reserved.

\section{Introduction}

The $\gamma$-aminobutyric (GABA)-ergic system is the most important inhibitory mechanism in the adult mammalian brain. ${ }^{1}$ The GABA neurotransmitter binds to $\mathrm{GABA}_{\mathrm{A}}$ receptors $\left(\mathrm{GABA}_{\mathrm{A}}-\mathrm{Rs}\right)$, members of the Cys-loop family of ligand gated ion channels (LGICs) and to metabotropic G-protein-coupled $G_{A B A}$ receptors. ${ }^{2} G_{A B A}-R s$ are pentameric trans-membrane proteins formed by a combination of 19 different subunits $(\alpha 1-6, \beta 1-3, \gamma 1-3, \delta, \varepsilon, \theta, \pi$, and $\rho 1-3$ ) with the most common composition being of two single alpha subunits, two single beta subunits, and one gamma subunit $\alpha_{2} \beta_{2} \gamma{ }^{3}$ The combination of the isoforms $\alpha 1-3,5, \beta 2 / 3$, and $\gamma 2$ form a subset of $\mathrm{GABA}_{\mathrm{A}}-\mathrm{Rs}(\alpha 1 \beta 2 \gamma 2, \alpha 2 \beta 3 \gamma 2, \alpha 3 \beta 3 \gamma 2$, and $\alpha 5 \beta 3 \gamma 2)$ modulated by benzodiazepines (Bzs) and by non-benzodiazepine ligands belonging to several chemical classes. The Bz binding site is located at the interface of an $\alpha$ and a $\gamma$ subunit and its pharmacology is mainly determined by the isoforms of these two subunits.

\footnotetext{
* Corresponding author. Tel.: +39055 4573766; fax: +39055 4573671 .

E-mail address: gabriella.guerrini@unifi.it (G. Guerrini).
}

Subunit $\beta$, although needed to generate a functional GABA gated ion channel, does not affect the sensitivity to the Bz site. Using genetically engineered mice and comparing drug-induced behavioral responses in mutated and wild-type mice, with respect to diazepam, ${ }^{4-6} \mathrm{GABA}_{\mathrm{A}}-\mathrm{R}$ subtype functions have been identified. The $\alpha 1 \beta 2 \gamma 2$ receptors mediate the sedative, anterograde amnesic and anticonvulsant actions of diazepam. ${ }^{7-9}$ The anxiolytic-like effect and the muscle relaxant activities are mediated by the $\alpha 2 \beta \gamma 2$ and $\alpha 3 \beta \gamma 2$ receptors even if the $\alpha 3$-containing $G_{A B A}-R s$ seem to be involved in the inhibitory input for the dopaminergic system. ${ }^{10-12}$ The $\alpha 5 \beta \gamma 2$ receptors, that are preferentially localized in the hippocampus, seem to influence learning and memory. ${ }^{1}$

Currently, the unified pharmacophore/receptor model for ligands at the Bzs site on the $\mathrm{GABA}_{\mathrm{A}}$-Rs developed by Cook et al., ${ }^{13}$ has been updated ${ }^{14}$ and correlated with a comparative model ${ }^{15}$ to individuate residues relative to descriptors of the pharmacophore/receptor model.

To increase our understanding of the requirements of the Bzs site on $G_{A B A}-R$, we have developed a pharmacophoric model based on pyrazolo[5,1-c][1,2,4]benzotriazine ligands, ${ }^{16}$ using ADLR procedure. This procedure allowed us to identify the essential 


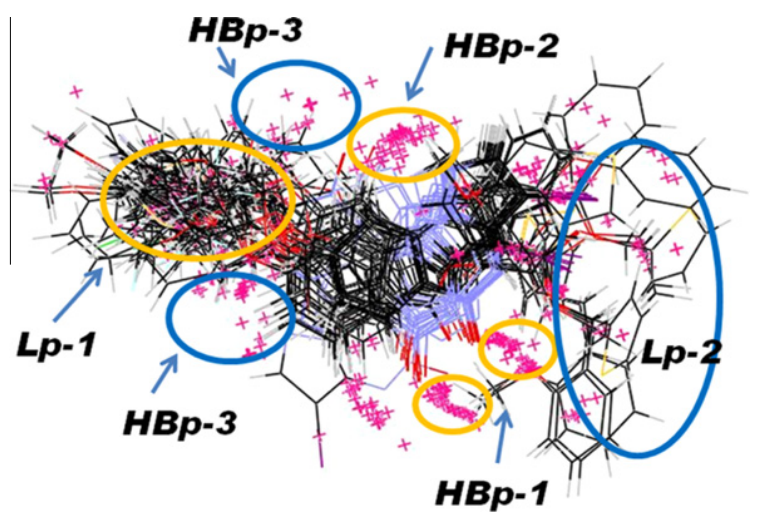

Figure 1. Overlapping of ligand conformations following the ADLR procedure: the figure shows the essential interaction points for binding recognition (yellow circles) and the important areas for affinity modulation (blue circles).

interaction points for binding recognition (HBp-1, HBp-2, and Lp-1) and the important areas for affinity modulation (HBp-3 and Lp-2) of the pyrazolobenzotriazine system, Figure 1.

Table 1

Chemical data for new synthesized compounds<smiles>[R5]c1ccc2c(c1)n1ncc(Br)c1n[n+]2[O-]</smiles><smiles>CCOC(=O)c1cnn(-c2cc(-c3ccco3)ccc2[N+](=O)[O-])c1N</smiles>

At the same time, we elaborated structure-activity/affinity relationships for the pyrazolobenzotriazine system 3-, 8-disubstituted, identifying the heteroaryl groups, the thienylmethoxycarbonyl group ${ }^{17}$ the iodine atom, ${ }^{18}$ and the furoyl group ${ }^{19}$ as better 3 -substituents, ${ }^{20}$ and, as 8 -substituents, the groups endowed with different electronic/steric features (alkyl, thioalkyl, alkyloxy, halogen, aryloxy, and difluoromethoxy). ${ }^{16,21-23}$ Among these compounds, it was very intriguing to modify the 8-aryloxy derivatives for which it was hypothesized that the 8-oxygen atom engaged a hydrogen bond interaction with the HBp-3 area. ${ }^{16}$ In this paper we have decided to investigate the 8 -aryl/heteroaryl derivatives, ${ }^{16}$ maintaining at position 3 the better previously identified substituents. These modifications (introduction at position 8 of aryl/heteroaryl rings) permit us to evaluate whether the HBp-3 area is involved or if other receptor interactions can occur $(\pi-\pi$ stacking, hydrophobic interaction...) and to measure the size and shape of lipophilic regions Lp-1 and Lp-2.

\section{Chemistry}

All compounds described here are listed in Table 1 (chemical data).

3-28, 30, 32-37, 40-42 39

\begin{tabular}{|c|c|c|c|c|}
\hline Compd $^{\mathrm{a}}$ & $\mathrm{R}_{3}$ & $\mathrm{R}_{8}$ & Yield (\%) & $\mathrm{Mp}{ }^{\circ} \mathrm{C}$ (recryst. solvent) \\
\hline 3 & $\mathrm{H}$ & 2-OMePh & 60 & 190-192 (ethanol) \\
\hline 4 & $\mathrm{H}$ & 4-OMePh & 54 & 196-197 (ethanol) \\
\hline 5 & $\mathrm{H}$ & 4-Py & 52 & $220-222$ (ethanol) \\
\hline 6 & $\mathrm{H}$ & 2-Thienyl & 65 & 200-202 (ethanol) \\
\hline 7 & $\mathrm{H}$ & 3-Thienyl & 73 & 206-207 (ethanol) \\
\hline 8 & $\mathrm{H}$ & 2-Furyl & 67 & 201-202 (ethanol) \\
\hline 9 & $\mathrm{H}$ & 1-Boc-2-pyrrolyl & 70 & 196-198 (ethanol) \\
\hline 10 & I & 2-OMePh & 40 & 212-214 (ethanol) \\
\hline 11 & I & 2-OHPh & 35 & 250-251 (ethanol) \\
\hline 12 & I & 4-OMePh & 45 & 234-236 (ethanol) \\
\hline 13 & I & 4-Py & 27 & 267-269 (ethanol) \\
\hline 14 & I & 2-Thienyl & 54 & 247-248 (ethanol) \\
\hline 15 & I & 3-Thienyl & 45 & 258-259 (methoxyethanol) \\
\hline 16 & I & 2-Furyl & 50 & 215-216 (ethanol) \\
\hline 17 & I & 1-Boc-2-pyrrolyl & 45 & 207-208 (ethanol) \\
\hline 18 & I & (1H)-2-Pyrrolyl & 30 & $>300$ (ethanol) \\
\hline 19 & 3-Thienyl & $\mathrm{Ph}$ & 25 & 237-238 (ethanol) \\
\hline 20 & 3-Thienyl & 4-OMePh & 56 & $250-252$ dec (chromatography) \\
\hline 21 & 3-Thienyl & 2-Thienyl & 30 & $229-230$ (methoxyethanol) \\
\hline 22 & 3-Thienyl & 3-Thienyl & 25 & 233-234 (methoxyethanol) \\
\hline 23 & 3-Thienyl & 2-Furyl & 84 & 240-241 (ethanol) \\
\hline 24 & 3-Thienyl & 1-Boc-2-pyrrolyl & 45 & 196-198 dec (ethanol) \\
\hline 25 & 3-Thienyl & (1H)-2-Pyrrolyl & 77 & $>300$ (ethanol) \\
\hline 26 & 2-Furyl & 3-Thienyl & 37 & 249-250 (chromatography) \\
\hline 27 & 1-Boc-2-pyrrolyl & 3-Thienyl & 57 & 194-195 dec (ethanol) \\
\hline 28 & (1H)-2-Pyrrolyl & 3-Thienyl & 72 & 219-220 (ethanol) \\
\hline 30 & CO-2-furyl & I & 30 & 233-234 (chromatography) \\
\hline 32 & $\mathrm{COOCH}_{2}$-2-thienyl & 4-OMePh & 21 & 200-202 (chromatography) \\
\hline 33 & $\mathrm{COOCH}_{2}$-2-thienyl & 1-Boc-2-pyrrolyl & 80 & $138-140 \mathrm{dec}$ (ethanol) \\
\hline 34 & $\mathrm{COOCH}_{3}$ & (1H)-2-Pyrrolyl & 69 & $>300$ (ethanol) \\
\hline 35 & CO-2-furyl & $4-\mathrm{OMePh}$ & 21 & 258-259 (chromatography) \\
\hline 36 & CO-2-furyl & 1-Boc-2-pyrrolyl & 73 & $184-186 \mathrm{dec}$ (ethanol) \\
\hline 37 & CO-2-furyl & (1H)-2-Pyrrolyl & 78 & $>300$ (ethanol) \\
\hline 39 & COOEt & 2 -furyl & 90 & 140-142 (ethanol) \\
\hline 40 & $\mathrm{COOH}$ & 2-furyl & 58 & 279-280 (ethanol) \\
\hline 41 & $\mathrm{COOCH}_{2}$-2-thienyl & 2-Furyl & 23 & 215-216 (ethanol) \\
\hline 42 & CO-2-furyl & 2-Furyl & 35 & 230-233 dec (ethanol) \\
\hline
\end{tabular}

\footnotetext{
a Compound 1-2, 29, 31, and 38 known, see chemical section for references. Compound 39, ethyl 1-(2-nitro-5-fur-2-ylphenyl)-5-aminopyrazole-4-carboxylate.
} 
The Suzuki coupling reaction on suitable iodinate starting material was used for the synthesis of all 3-aryl-, 8-aryl-, and 3,8-diarylderivatives. As reported in Scheme 1, the 8-iodopyrazolo[5,1-c][1,2,4]benzotriazine 5 -oxide, ${ }^{18} \mathbf{1}$, was used to obtain the 8-aryl derivatives 3-9, using the suitable arylboronic acid.

The reaction with 2 -furylboronic acid produced several problems, and for the synthesis of compound $\mathbf{8}$, the most versatile and stable potassium 2-furantrifluoroborate in presence of the palladium catalyst, palladiumchloride (diphenylphosphine-ferrocene) $\mathrm{PdCl}_{2}$ (dppf) $\cdot \mathrm{CH}_{2} \mathrm{Cl}_{2}$ was used as the coupling partner. ${ }^{24,25}$ (All the 3- and/or 8-(2-furyl) derivatives were synthesized following this procedure). Compounds 3-9 were in turn iodinated at position 3 with ceric ammonium nitrate (CAN) and iodine ${ }^{26}$ to give derivatives 10, 12-17 which are useful for structure-affinity relationships. The demethylation of derivative $\mathbf{1 0}$ with $\mathrm{CH}_{2} \mathrm{Cl}_{2} / \mathrm{BBr}_{3}$ gave the corresponding 2-hydroxyphenyl derivative 11, while the deprotection of $\mathbf{1 7}$ was realized with $\mathrm{NaOCH}_{3} / \mathrm{CH}_{3} \mathrm{OH}$ in $\mathrm{THF}^{27}$ to give 18. The starting material 3-(3-thienyl)-8-iodopyrazolo[5,1c] $[1,2,4]$ benzotriazine 5 -oxide, ${ }^{22} \mathbf{2}$, was instead used to obtain derivatives 19-24. The deprotection of $\mathbf{2 4}$ was realized in the same previously described conditions, ${ }^{27}$ and compound 25 was obtained.

To obtain the 8-(3-thienyl)-3-heteroaryl substituted derivatives, 26-27 (Scheme 2), compound $\mathbf{1 5}$ was used as starting material for the Suzuki coupling. The deprotection of $\mathbf{2 7}$ afforded the pyrrole derivative 28 .

Scheme 3 depicts the synthetic pathway for obtaining derivatives 32-37. The starting material is 3-carboxy-8-iodopyrazolo[5,1-c] $[1,2,4]$ benzotriazine 5-oxide, $\mathbf{2 9}, 22$ that was reacted by a Friedel-Craft reaction with thionyl chloride, $\mathrm{SnCl}_{4}$, and furane ${ }^{19}$ to obtain the new 3-(fur-2-ylcarbonyl)-8-iodopyrazolo[5,1-c]$[1,2,4]$ benzotriazine 5-oxide, 30.

Following a described procedure, compound $\mathbf{2 9}$ was also used to obtain 3-(2-thienylmethoxycarbonyl)-8-iodopyrazolo[5,1-c]$[1,2,4]$ benzotriazine 5-oxide, 31. ${ }^{22}$ Both compounds $\mathbf{3 0}$ and $\mathbf{3 1}$ were subjected to Suzuki coupling and derivatives 32, 33, 35, and 36 were synthesized. The treatment of derivative $\mathbf{3 3}$ with $\mathrm{NaOCH}_{3} / \mathrm{CH}_{3} \mathrm{OH}$ caused, at the same time, pyrrole deprotection and trans-esterification, producing derivative 34 . In the same

\begin{tabular}{c|l}
$\mathbf{N}^{\circ}$ & \multicolumn{1}{|c}{$\mathbf{8 - A r} / \mathbf{H e t}$} \\
\hline $\mathbf{3}$ & 2-OMe-Ph \\
$\mathbf{4}$ & 4-OMe-Ph \\
$\mathbf{5}$ & 4-Py \\
$\mathbf{6}$ & 2-thienyl \\
$\mathbf{7}$ & 3-thienyl \\
$\mathbf{8}$ & 2-furyl \\
$\mathbf{9}$ & 1-Boc-2-pyrrolyl
\end{tabular}

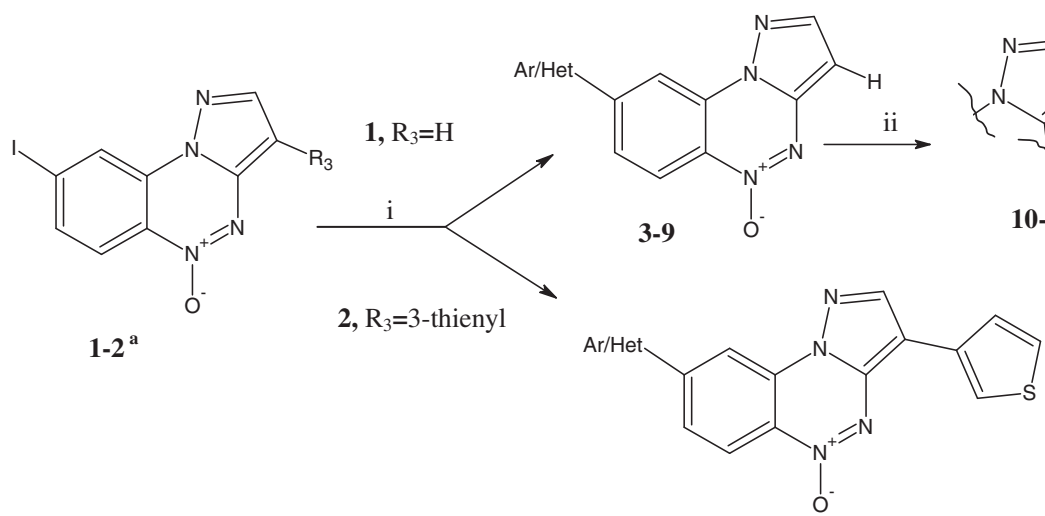

$19-25$

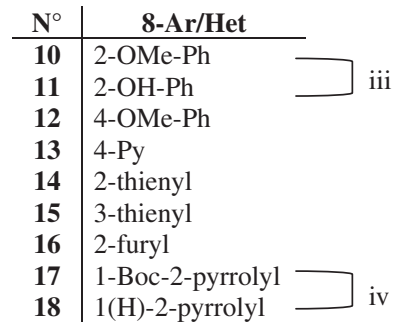<smiles>CCc1c(I)cnn1CC</smiles>

10-18

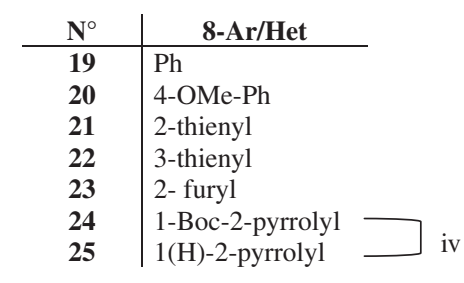

Scheme 1. For compound 1 see, ${ }^{18}$ for compound 2 see $^{22}$ Reagents: (i) Suzuki conditions, Arylboronic acids, ethanol abs, $(\mathrm{PPh})_{4} \mathrm{Pd}$ tetrakis(triphenylphosphine)palladium (0), sodium carbonate $2 \mathrm{M}$; for synthesis of derivatives $\mathbf{8}$ and 23, potassium 2-furyltrifluoroborate, $n$-propanol, $\mathrm{TEA}_{2} \mathrm{PdCl}{ }_{2}\left(\mathrm{dppf}\right.$ ); (ii) $\mathrm{I}_{2} / \mathrm{CAN} / \mathrm{CH}_{3} \mathrm{CN}$; (iii) for hydrolysis of compound $\mathbf{1 0}, \mathrm{CH}_{2} \mathrm{Cl}_{2} / \mathrm{BBr}_{3}$; (iv) for deprotection of $\mathrm{N}$-Boc derivatives (17 and $\mathbf{2 4}$ ) $\mathrm{THF} / \mathrm{MeONa}$.

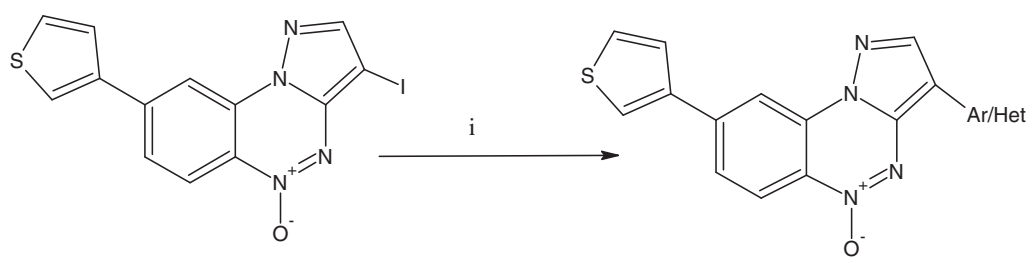

15

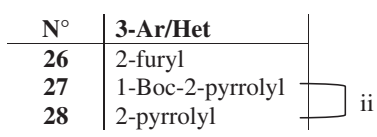

Scheme 2. Reagents: (i) Suzuki conditions, potassium 2-furyltrifluoroborate, n-propanol, $\mathrm{TEA}, \mathrm{PdCl}_{2}(\mathrm{dppf})$ and $\mathrm{N}$-(Boc)pyrrole-2-boronic acid, ethanol abs, (PPh $)_{4} \mathrm{Pd}$ tetrakis(triphenylphosphine)palladium (0), sodium carbonate $2 \mathrm{M}$; (ii) for deprotection of $N$-Boc derivative (27) THF/MeONa. 


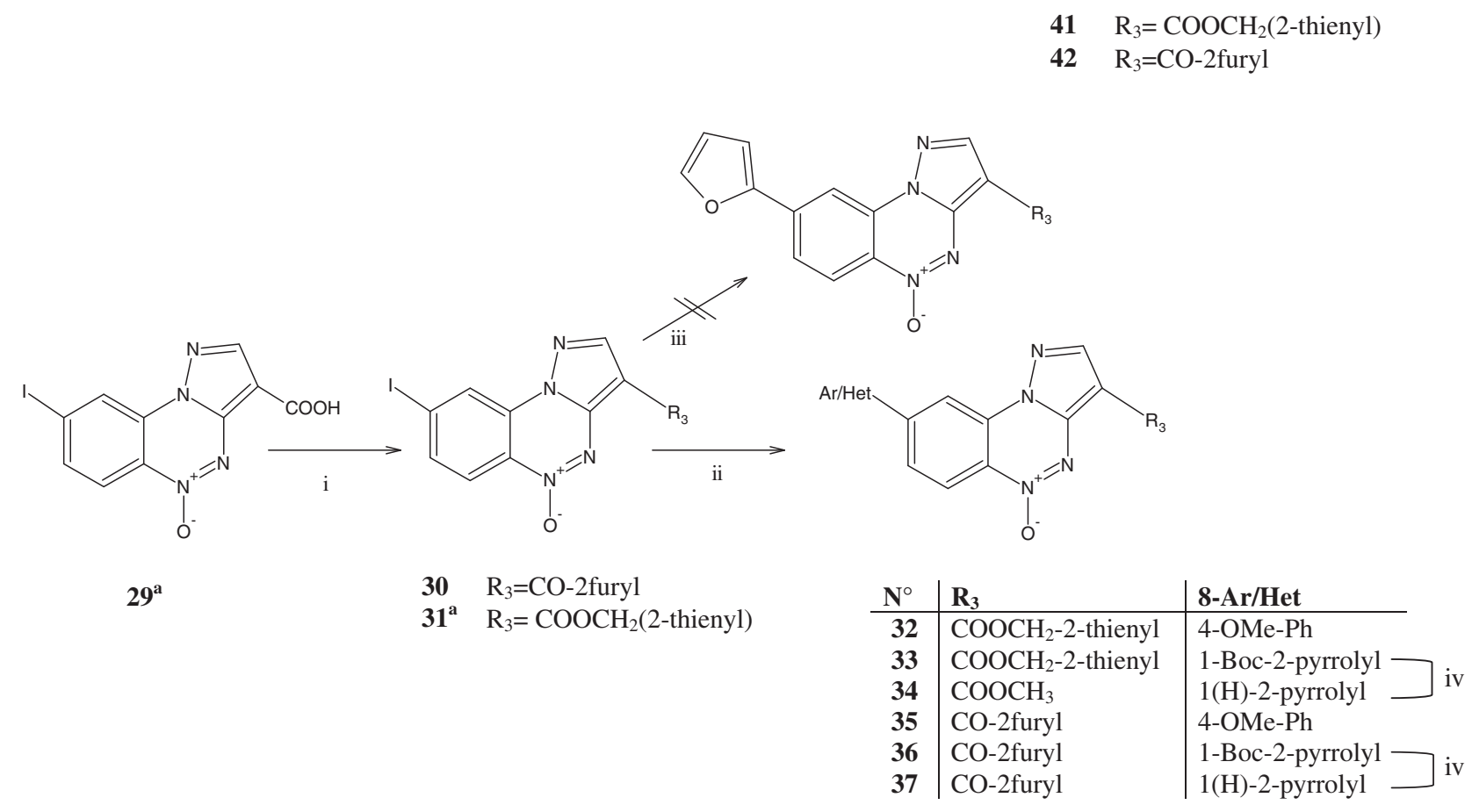

Scheme 3. For compound $\mathbf{2 9}$ and $\mathbf{3 1} \mathrm{see}^{22}$ : Reagents: (i) Friedel-Craft reaction on 29, 3-carboxy-8-iodopyrazolo[5,1-c][1,2,4]benzotriazine 5-oxide, 22 to obtain 30: thionyl chloride $/ \mathrm{CH}_{2} \mathrm{Cl}_{2} / \mathrm{SnCl}_{4} /$ furane; starting from 29, following a procedure described in ${ }^{22}$ to obtain 31; (ii) Starting material 30 or 31, ${ }^{22}$ reacted in Suzuki conditions: 4methoxyphenylboronic acid for compound 32 and 35, $\mathrm{N}$-Boc-2-pyrrolylboronic acid for compounds $\mathbf{3 3}$ and 36, ethanol abs, tetrakis, sodium carbonate $2 \mathrm{M}$; (iii) potassium 2furyltrifluoroborate, $n$-propanol, TEA, $\mathrm{PdCl}_{2}$ (dppf); (iv) for deprotection of $\mathrm{N}$-Boc derivatives (33 and $\mathbf{3 6}$ ) THF/MeONa. In case of derivative $\mathbf{3 3}$ in this reaction condition a trans-esterification occurred, obtained compound $\mathbf{3 4}$.<smiles>CCOC(=O)c1cnn(-c2cc(I)ccc2[N+](=O)[O-])c1N</smiles>

$38^{\mathrm{a}}$

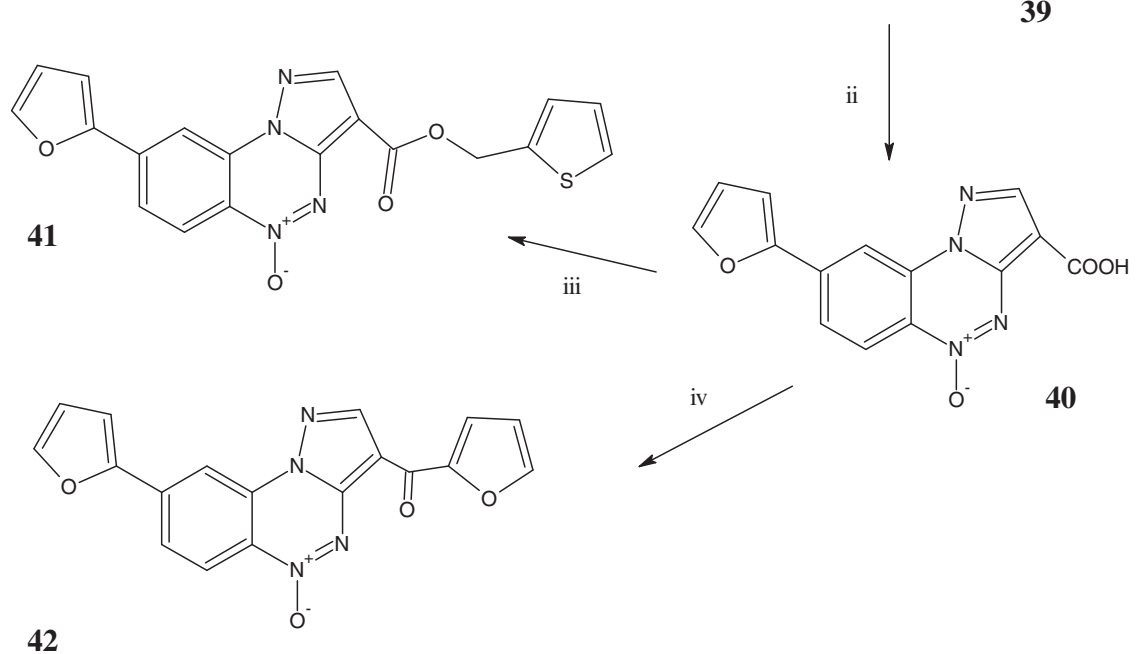<smiles>CCOC(=O)c1cnn(-c2cc(-c3ccco3)ccc2[N+](=O)[O-])c1N</smiles>

39 
using again potassium 2-furantrifluoroborate and palladium chloride(diphenylphosphine ferrocene) $\mathrm{PdCl}_{2}(\mathrm{dppf}) \cdot \mathrm{CH}_{2} \mathrm{Cl}_{2}$ and $\mathbf{3 9}$ was obtained in good yield.

The next cyclization in alkali medium ${ }^{28}$ gave the 3 -carboxy-8(2-furyl)pyrazolo[5,1-c][1,2,4]benzotriazine 5-oxide 40, that was esterified by the mixed anhydride method (triethyl amine/i-butylchloroformate and 2-thiophenmethanol), to yield compound $\mathbf{4 1}$. The same compound $\mathbf{4 0}$ was transformed into corresponding acid chloride in mild conditions, by treatment with trichloroacetonitrile and triphenylphosphine in methylene chloride ${ }^{29}$; this acyl chloride was not isolated, but subjected to a Friedel-Craft reaction with $\mathrm{SnCl}_{4}$ and furane to obtain derivative $\mathbf{4 2}$.

\section{Results and discussion}

\subsection{Biological results}

The affinity at the $\mathrm{Bz}$ site on $\mathrm{GABA}_{\mathrm{A}}-\mathrm{R}$ of the new synthesized compounds was evaluated by their ability to displace $\left[{ }^{3} \mathrm{H}\right]$ flumazenil (Ro 15-1788) from its specific binding in bovine brain membrane. ${ }^{19}$ The affinity was expressed as $K_{\mathrm{i}}$ only for those compounds inhibiting radioligand binding by more than $80 \%$ at fixed concentrations of $10 \mu \mathrm{M}$

From the binding results reported in Table 2, some observations arise. The new tested compounds show receptor recognition with a $K_{\mathrm{i}}$ range of $14.9-2480 \mathrm{nM}$. Compounds 3-9 as well as compound 40, (Table 1) were not tested because previous reports indicate that these types of derivatives have no receptor recognition. ${ }^{21}$

Among the 3-iodopyrazolo[5,1-c][1,2,4]benzotriazine 5-oxides, bearing various aryl/heteroaryl rings at position $8, \mathbf{1 0 - 1 8}$, the features of ring moiety are very important. In fact, the optimization of the 8-phenyl derivative, A27, ${ }^{16}\left(K_{\mathrm{i}}=966 \mathrm{nM}\right)$, that is, compounds 10 and 12, allow a threefold higher binding affinity: 10, $K_{\mathrm{i}}=305 \mathrm{nM}$ and $12 K_{\mathrm{i}}=241 \mathrm{nM}$. These compounds have a methoxy group in the phenyl ring (ortho- and para-position, respectively) that could reinforce the interaction with receptor protein. ${ }^{16}$

A more hydrophilic substituent at position 8 is detrimental for the binding as shown for compound $11\left(K_{\mathrm{i}}=2480 \mathrm{nM}\right)$, obtained from demethylation of $\mathbf{1 0}$ and for the 8-(4-pyridyl)-derivative $\left(K_{\mathrm{i}}=2380 \mathrm{nM}\right)$, compound 13. The isosteric replacement of the 8-phenyl ring with five-membered heteroaryl rings 2-, 3-thienyl, 2-furyl and (1H)-2-pyrrolyl gave compounds 14-16 and 18. The best affinity was shown by derivative (1H)-2-pyrrolyl, 18 $\left(K_{\mathrm{i}}=25 \mathrm{nM}\right)$, that contains a hydrogen bond donor atom $(\mathrm{NH})$. Among the other heteroaryl rings, only the 8-(3-thienyl) derivative 15 is endowed with good binding affinity $\left(K_{\mathrm{i}}=56 \mathrm{nM}\right)$ compared to the 8-(2-thienyl), 14, $K_{\mathrm{i}}=202 \mathrm{nM}$ and the 8-(2-furyl), 16, $K_{\mathrm{i}}=190 \mathrm{nM}$. These results suggest that the smaller size of the 8substituents versus phenyl ring $\left(K_{\mathrm{i}}=966 \mathrm{nM}\right)$ permits better receptor interaction.

In the series of the 3-thienyl derivatives $(\mathbf{1 9 - 2 3}, \mathbf{2 5})$ the introduction at position 8 of aromatic/heteroaromatic rings gave useful information. The 8-phenyl derivative 19 shows a poor binding affinity $\left(K_{\mathrm{i}}=642 \mathrm{nM}\right)$, as well as the $8-\left(4-\mathrm{OCH}_{3}\right.$ phenyl) derivative, 20, $K_{\mathrm{i}}=817 \mathrm{nM}$. When in position 8 was introduced a five-membered ring, 2-, 3-thienyl, 2-furyl and (1H)-2-pyrrolyl, 21-23 and 25, the receptor recognition falls in the range of 370-19.4 $K_{\mathrm{i}}(\mathrm{nM})$, confirming again the importance of ring size. In particular, the need of hydrogen bond donor moiety ( $\mathrm{NH}$ pyrrole) is evidenced as for compound $\mathbf{2 5}\left(K_{\mathrm{i}}=19.4 \mathrm{nM}\right)$, while the presence of an acceptor moiety (furane oxygen) gave weak affinity $\left(\mathbf{2 3}, K_{\mathrm{i}}=209 \mathrm{nM}\right)$. We thought that it might be useful to invert the substituents of positions 3 and 8 of compounds $\mathbf{2 3}$ and $\mathbf{2 5}$ to evaluate the influence of their interchangeability in receptor protein recognition, thus obtaining compounds $\mathbf{2 6}$ and $\mathbf{2 8}$. The various orientations that
Table 2

BZR ligand affinity of new 8-aryl-/heteroarylpyrazolo[5,1-c][1,2,4]benzotriazine 5oxide 3-substituted

\begin{tabular}{|c|c|c|c|}
\hline $\mathrm{N}^{\circ}$ & $\mathrm{R}_{3}$ & $\mathrm{R}_{8}$ & $K_{\mathrm{i}}(\mathrm{nM})^{\mathrm{a}}$ \\
\hline $\mathrm{A}^{2} 7^{\mathrm{b}}$ & I & $\mathrm{Ph}$ & $966 \pm 95$ \\
\hline 10 & I & 2-OMePh & $305 \pm 29.3$ \\
\hline 11 & I & 2-OHPh & $2480 \pm 120$ \\
\hline 12 & I & 4-OMePh & $241 \pm 23.2$ \\
\hline 13 & I & 4-Py & $2380 \pm 190$ \\
\hline 14 & I & 2-Thienyl & $202 \pm 20$ \\
\hline 15 & I & 3-Thienyl & $56 \pm 4.9$ \\
\hline 16 & I & 2-Furyl & $190 \pm 22$ \\
\hline 18 & I & (1H)-2-Pyrrolyl & $25 \pm 2.4$ \\
\hline 19 & 3-Thienyl & $\mathrm{Ph}$ & $642 \pm 62.6$ \\
\hline 20 & 3-Thienyl & 4-OMePh & $817.0 \pm 16.7$ \\
\hline 21 & 3-Thienyl & 2-Thienyl & $370 \pm 35.7$ \\
\hline 22 & 3-Thienyl & 3-Thienyl & $357 \pm 33.9$ \\
\hline 23 & 3-Thienyl & 2-Furyl & $209 \pm 20$ \\
\hline 25 & 3-Thienyl & (1H)-2-Pyrrolyl & $19.4 \pm 2.8$ \\
\hline 26 & 2-Furyl & 3-Thienyl & $26.9 \pm 2.5$ \\
\hline 28 & (1H)-2-pyrrolyl & 3-Thienyl & $48.3 \pm 6.1$ \\
\hline 32 & $\mathrm{COOCH}_{2}$-2-thienyl & 4-OMePh & $29.4 \pm 1.8$ \\
\hline 33 & $\mathrm{COOCH}_{2}$-2-thienyl & 1-Boc-2-pyrrolyl & $395.4 \pm 39$ \\
\hline 34 & COOMe & (1H)-2-Pyrrolyl & $14.9 \pm 1.1$ \\
\hline 41 & $\mathrm{COOCH}_{2}$-2-thienyl & 2-Furyl & $54.8 \pm 4.1$ \\
\hline 35 & CO-2-furyl & 4-OMePh & $238.67 \pm 18$ \\
\hline 37 & CO-2-furyl & (1H)-2-Pyrrolyl & $63.0 \pm 5.5$ \\
\hline 42 & CO-2-furyl & 2-Furyl & $856.9 \pm 4.2$ \\
\hline
\end{tabular}

$K_{\mathrm{i}}$ value are means \pm SEM of five determinations.

See Ref. 16

the pyrazolobenzotriazine scaffold assumes, when selected by ADLR model, show that the substituents at position 3 and 8 can interact indiscriminately with the pharmacophoric points Lp- 1 or Lp-2 in case of lipophilic moiety and HBp-1, HBp-2, or HBp-3 in case of a moiety able to form a hydrogen bond interaction. ${ }^{16,23}$ This would explain the good affinity shown by 3-(2-furane derivative), $26\left(K_{\mathrm{i}}=26.9 \mathrm{nM}\right)$ compared to its isomer 23 (8-(2-furane derivative, $K_{\mathrm{i}}=209 \mathrm{nM}$ ), that probably has less interaction strength. The two pyrrole derivative isomers, instead, have good affinity: 3(1(H)-2-pyrrol-) derivative 28, $K_{\mathrm{i}}=48.3 \mathrm{nM}$ and 8- $(1(H)$-2-pyrrol) derivative $\mathbf{2 5}, K_{\mathrm{i}}=19.4 \mathrm{nM}$. (We are going to rationalize these results in the next molecular modeling section).

The (hetero)aryl rings at position 8 in the 3 -ester derivatives, 32-34, 41, were chosen considering the influence, positive or negative, which they have in the two previous series. In the 3-ester series the negligible influence of the ring size at position 8 was seen, in fact the affinity value is in the same order of magnitude $\left(14.9 \leqslant K_{\mathrm{i}}(\mathrm{nM}) \leqslant 54.8\right)$ for all compounds, except derivative 33 , $\left(K_{\mathrm{i}}=395.4 \mathrm{nM}\right)$. The presence of a six-membered ring (paramethoxyphenyl), as in derivative $\mathbf{3 2}$, or five-membered ring, compound 41, confers quite comparable affinity values, $32 K_{\mathrm{i}}=29.4 \mathrm{nM}$ and $41 K_{\mathrm{i}}=54.8 \mathrm{nM}$. When position 8 was substituted with a 2$(1 H)$-pyrrolyl, as in the case of the 3-methoxycarbonyl derivative 34, the affinity value was the best, $K_{\mathrm{i}}=14.9 \mathrm{nM}$. The $\mathrm{NH}$ pyrrole protection, as in compound 33 , reduced the affinity value confirming the importance of the $\mathrm{NH}$ pyrrole in the binding. Thus, the importance of anchorage of the 3 -ester group is again confirmed ${ }^{17}$ and the affinity modulation due to substituent at position 8 is emphasized. ${ }^{16}$

The importance of the type of 8-substituent in the 3-furoyl derivatives, 35, 37, 42 that show binding affinity values in the 
range of $63 \leqslant K_{\mathrm{i}}(\mathrm{nM}) \leqslant 856$ is again verified. Compound 37, the 8$(1 H)-2$-pyrrolyl emerges for its good affinity, $K_{\mathrm{i}}=63 \mathrm{nM}$.

From binding results it is possible assert that compounds bearing the $(1 H)-2$-pyrrolyl moiety are very good ligands $(\mathbf{1 8}, \mathbf{2 5}, \mathbf{2 8}$, 34, and 37) in each series, suggesting the critical role of a hydrogen bond donor (pyrrole $\mathrm{NH}$ ) in receptor recognition. Good affinity values were also identified for compounds bearing acceptor atom moiety $(\mathbf{2 6}, \mathbf{3 2}$, and $\mathbf{4 1})$ if only by having the suitable substituent in the complementary position. Moreover, the size of the substituent at position 8 is very important only in the 3-iodine-, 3-heteroaryl-, and 3-furoylderivative, while it is negligible in the 3-ester series.

\subsection{Molecular modeling}

The ADLR method ${ }^{16,23}$ was used here to rationalize the affinity data and to improve our knowledge of the HBp-3 area. Among the compounds endowed with better binding affinity, emerge derivatives with the pyrrole moiety in position 8 or $3(\mathbf{1 8}, \mathbf{2 5}, \mathbf{3 4}$, 37, and 28). In the overlapping performed by ADLR, the pyrrole ring fits in the HBp-3 area permitting the $\mathrm{NH}$ to form hydrogen bond interaction, independently of the position of the pyrrole moiety in the pyrazolobenzotriazine core (see Fig. 2).

When the pyrrole ring is replaced with furane $(\mathbf{1 6}, \mathbf{2 3}, \mathbf{4 2}, \mathbf{4 1}$, and 26, Figs. 3 and 4) bearing a potential hydrogen bond acceptor atom (O), ADLR oriented the furane oxygen mainly toward the HBp-3 area. As depicted in Figure 3,compounds 16, 23, and 42 present the furane moiety in this mode, but the lower affinity value of compounds ( $K_{\mathrm{i}}=190,209$, and $856 \mathrm{nM}$, respectively) could be due to a reduced hydrogen bond force or no efficient interaction with LP-1 area (for $\mathbf{1 6}$ and 23) and steric hindrance for $\mathbf{4 2}$. Unexpectedly, compound $\mathbf{2 6}$ (isomer of compound 23) presents a different orientation proposed by ADLR (Fig. 4).

The thiophene ring efficiently interacts with the lipophilic area Lp-1, justifying the best affinity $\left(K_{\mathrm{i}}=26.9 \mathrm{nM}\right)$. Compound 41 bearing an ester group (the 2-thienylmethoxycarbonyl group) at position 3 shows a good affinity value $\left(K_{\mathrm{i}}=54.8 \mathrm{nM}\right)$ according to the fact that the ester group contributes significantly to receptor anchorage as previously stated, ${ }^{16}$ interacting with the lipophilic area Lp-1 or Lp-2 depending on the orientation (A or B), see Figure 5.

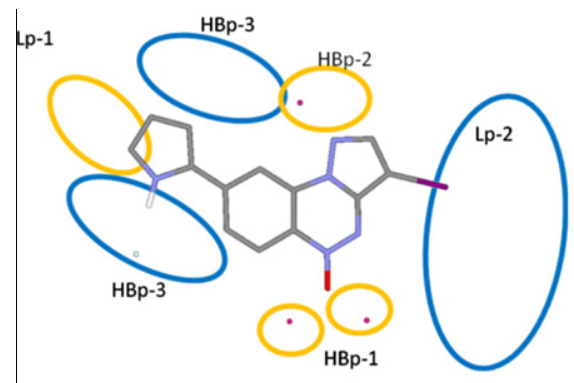

compound 18

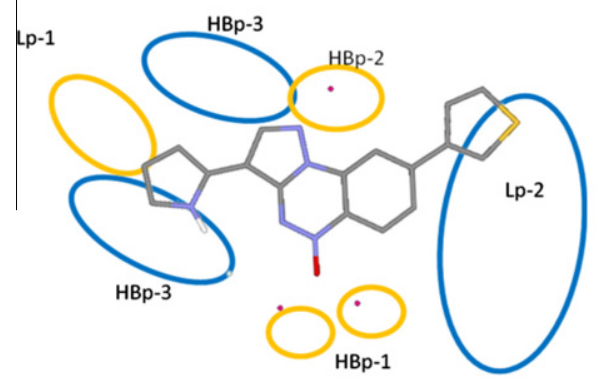

compound 28

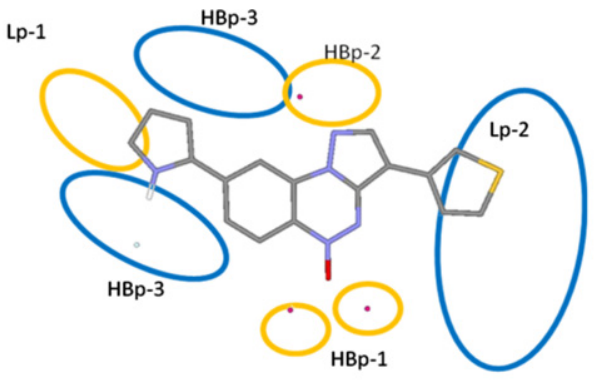

compound 25

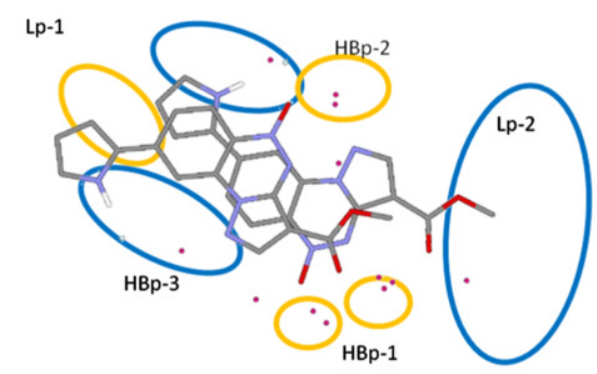

compound 34

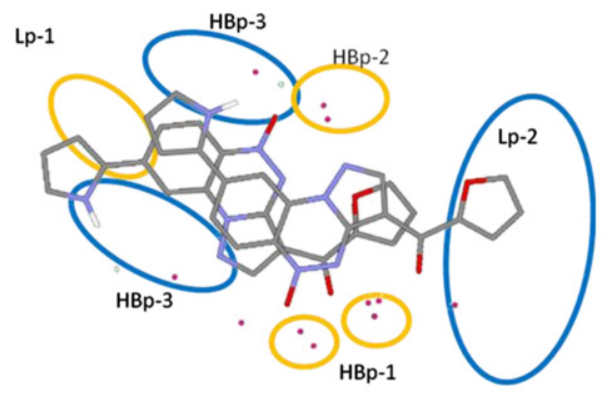

compound 37

Figure 2. Compounds $\mathbf{1 8}, \mathbf{2 5}, \mathbf{2 8}, \mathbf{3 4}$, and $\mathbf{3 7}$ in the pharmacophoric model performed by ADLR. The pyrrole ring fits in the HBp- 3 area permitting the NH moiety to form hydrogen bond interaction, independently of the position of the pyrrole moiety in the pyrazolobenzotriazine core. 


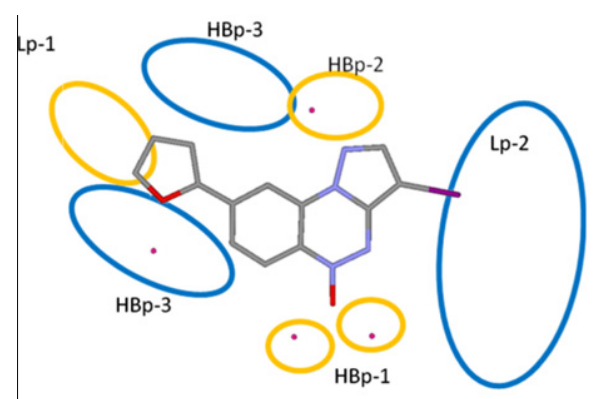

compound 16

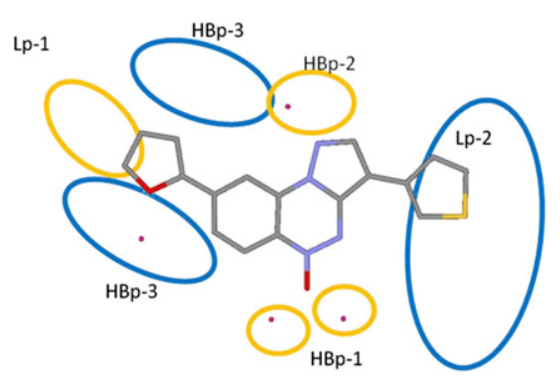

compound 23

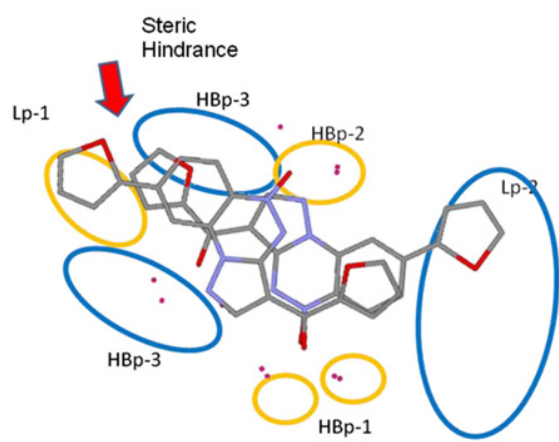

compound 42

Figure 3. Compounds $\mathbf{1 6}, \mathbf{2 3}, \mathbf{4 2}$ in the pharmacophoric model performed by ADLR. The furane ring is oriented toward the HBp-3, but a reduced hydrogen bond force in the HBp-3 area or no efficient interaction with Lp-1 area (16 and 23) and a steric hindrance $(\mathbf{4 2})$ are responsible of a low affinity $\left(\mathbf{1 6}, K_{\mathrm{i}}=190 \mathrm{nM} ; \mathbf{2 3}, K_{\mathrm{i}}=209 \mathrm{nM} ; \mathbf{4 2}\right.$, $\left.K_{\mathrm{i}}=856 \mathrm{nM}\right)$.

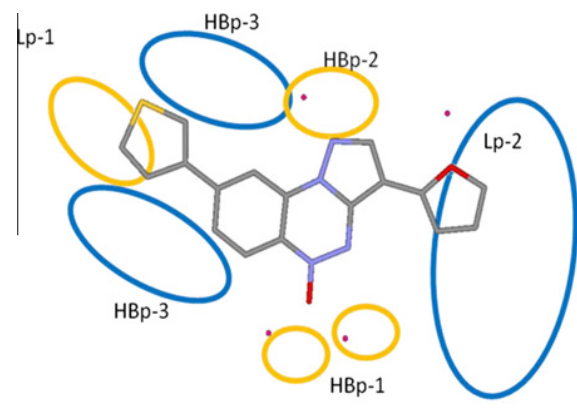

compound 26

Figure 4. Compounds 26 in the pharmacophoric model performed by ADLR: unexpected orientation of the furane ring; the driving force of the binding is due to lipophilic interaction of thiophene ring.

The importance of the anchorage by the ester group is also evidenced in compound $32\left(K_{\mathrm{i}}=29.4 \mathrm{nM}\right)$, in which the presence of a large size group at position 8 is not binding for affinity, Figure 5.

\section{Conclusion}

In previous studies it was hypothesized that the 8-oxygen atom of the 8-aryloxypyrazolo[5,1-c][1,2,4]benzotriazine 5-oxide derivatives engaged hydrogen bond interaction with the HBp-3 area. ${ }^{16}$ On the other hand, the idea/hypothesis that this HBp-3 was a bifunctional area arose when the CGS 9698 compound, used to validate our pharmacophoric model with respect to Cook's 'unified pharmacophore/receptor model', showed hydrogen bond interaction with the same area. In this study, this hypothesis is confirmed since the $\mathrm{NH}$ group of the pyrrole ring engages a strong hydrogen bond interaction with $\mathrm{HBp}-3$. The fact that the furane derivatives
(16, 23, and 42) do not have a good binding, despite the ability to form a hydrogen bond interaction through the oxygen atom, could be due to an imperfect distance from hydrogen bond donor in the HBp-3 area.

In a preliminary study (data not published) derivatives bearing a phenylethylamine moiety $\left(-\mathrm{NHCH}_{2} \mathrm{Ph}\right)$ at position 8 of pyrazolobenzotriazine system were endowed with very good binding affinity (in a range of $0.1 \mathrm{nM}$ ), thus the synthesis of $8-\mathrm{NH}$ isoster of $8-\mathrm{OAr}^{16}$ will be the object of our next research project.

\section{Experimental}

\subsection{Chemistry}

Melting points were determined with a Gallenkamp apparatus and were uncorrected. Silica gel plates $\left(\right.$ Merck $\left.F_{254}\right)$ and silica gel 60 (Merck 70-230 mesh) were used for analytical and column chromatography, respectively. The structures of all compounds were supported by their IR spectra (KBr pellets in nujol mulls, Perkin-Elmer 1420 spectrophotometer) and ${ }^{1} \mathrm{H}$ NMR data (measured with a Bruker $400 \mathrm{MHz}$ ). Chemical shifts were expressed in $\delta$ ppm, using DMSO- $d_{6}$ or $\mathrm{CDCl}_{3}$ as solvent. The chemical and physical data of new compounds are shown in Tables 1; all new compounds possess a purity $\geqslant 95 \%$ : microanalyses were performed with a Perkin-Elmer 260 analyzer for C, H, N.

\subsection{General procedure for the synthesis of $3-7,9,19-22,24,27$, 32-33, 35-36}

Tetrakis(triphenylphosphine)palladium (0) (20 mg, $0.017 \mathrm{mmol})$ and the suitable iodopyrazolo benzotriazine $(0.15 \mathrm{mmol})$ were combined in anhydrous tetrahydrofurane $(5.0 \mathrm{~mL})$. The starting materials were: compound $\mathbf{1},{ }^{18}$ for the synthesis of derivatives 


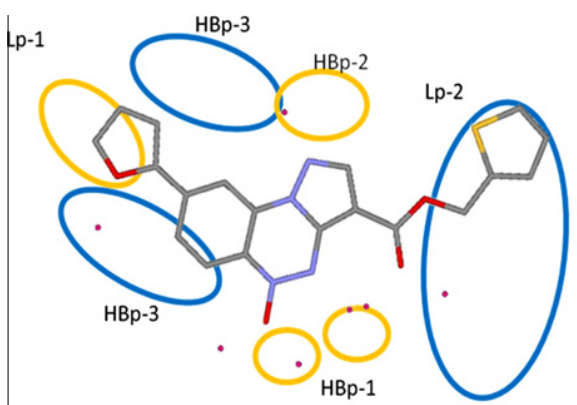

compound 41 (orientation A)

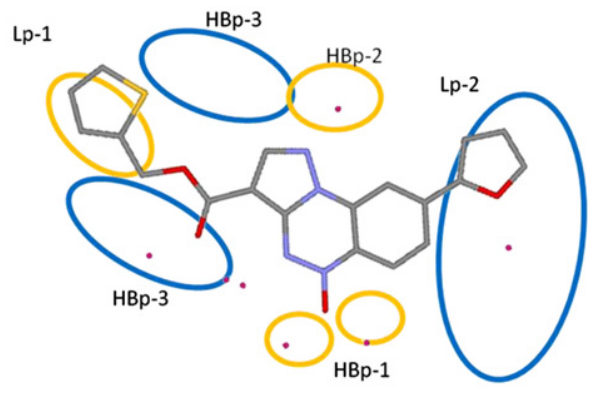

compound 41 (orientation B)

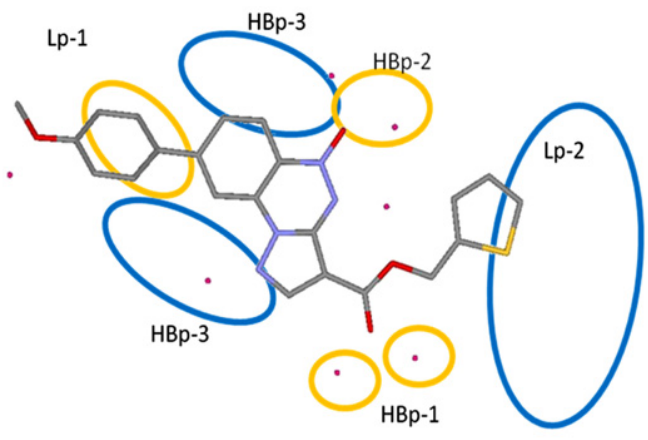

compound 32

Figure 5. Compounds 41 (in two orientations A, B) and compound 32 in the pharmacophoric model performed by ADLR. Contribute of ester group to receptor anchorage.

3-7, 9; compound $2,{ }^{22}$ for the synthesis of derivatives 19-22, 24; compound 15 (see below) for the synthesis of derivative 27; compound $\mathbf{3 0}$ for the synthesis of $\mathbf{3 5}$ and $\mathbf{3 6}$; compound $\mathbf{3 1},{ }^{22}$ for the synthesis of derivatives $\mathbf{3 2}$ and 33. The solution of the suitable arylboronic acid $(0.23 \mathrm{mmol}, 1: 1.5)$ in absolute ethanol and aqueous sodium carbonate $(2 \mathrm{M}, 2 \mathrm{~mL})$ were added and the reaction was maintained at $25-70{ }^{\circ} \mathrm{C}$ (see the exact condition in each compound) and monitored by TLC. The final suspension was treated with water, filtrated to crude final product and purified by recrystallization by suitable solvent.

\subsubsection{8-(2-Methoxyphenyl)pyrazolo $[5,1-c][1,2,4]$ benzotriazine 5-oxide (3)}

From $1,{ }^{18}$ and 2-methoxy phenylboronic acid, $4 \mathrm{~h}$, room temperature. Yellow crystals; TLC eluent: diisopropyl ether/cyclohexane $8: 3 \mathrm{v} / \mathrm{v} ;{ }^{1} \mathrm{H}$ NMR (DMSO- $\left.d_{6}\right) \delta 8.48(\mathrm{~m}, 2 \mathrm{H}, \mathrm{H}-6$ and $\mathrm{H}-9$ ); 8.29 (d, 1H, H-2); 7.87 (dd, 1H, H-7); 7.53 (m, 2H, H-4 and H-6 phenyl); 7.25 (d, $1 \mathrm{H}, \mathrm{H}-3$ phenyl); $7.16(\mathrm{t}, 1 \mathrm{H}, \mathrm{H}-5$ phenyl); 6.92 (d, $1 \mathrm{H}, \mathrm{H}-3) ; 3.85\left(\mathrm{~s}, 3 \mathrm{H}, \mathrm{OCH}_{3}\right)$. Anal. $\mathrm{C}, \mathrm{H}, \mathrm{N}$.

\subsubsection{8-(4-Methoxyphenyl)pyrazolo[5,1-c] $[1,2,4]$ benzotriazine 5-oxide (4)}

From 1, ${ }^{18}$ and 4-methoxyphenylboronic acid, $3 \mathrm{~h}$, room temperature. Yellow crystals; TLC eluent: toluene/ethyl acetate/acetic acid $8: 2: 1 \mathrm{v} / \mathrm{v} / \mathrm{v} ;{ }^{1} \mathrm{H}$ NMR (DMSO- $\left.d_{6}\right) \delta 8.48(\mathrm{~m}, 2 \mathrm{H}, \mathrm{H}-6$ and $\mathrm{H}-9$ ); 8.31 (d, 1H, H-2); 8.05 (dd, 1H, H-7); 7.92 (d, 2H, H-2 and H-6 phenyl); 7.15 (d, 2H, H-3 and H-5 phenyl); $6.92(\mathrm{~d}, 1 \mathrm{H}, \mathrm{H}-3) ; 3.85(\mathrm{~s}, 3 \mathrm{H}$, $\mathrm{OCH}_{3}$ ). Anal. C, $\mathrm{H}, \mathrm{N}$.

\subsubsection{8-(4-Pyridyl)pyrazolo $[5,1-c][1,2,4]$ benzotriazine 5 -oxide} (5)

From $1,{ }^{18}$ and 4 -pyridin boronic acid, $3 \mathrm{~h}$, reflux temperature. Yellow crystals; TLC eluent: toluene/ethyl acetate/acetic acid $8: 2: 1 \mathrm{v} / \mathrm{v} / \mathrm{v} ;{ }^{1} \mathrm{H}$ NMR (DMSO- $\left.\mathrm{d}_{6}\right) \delta 8.85(\mathrm{~m}, 2 \mathrm{H}, \mathrm{H}-2$ and $\mathrm{H}-6$ pyridine); 8.70 ( $\mathrm{m}, 2 \mathrm{H}, \mathrm{H}-6$ and $\mathrm{H}-9) ; 8.18$ (d, 1H, H-2); 7.90 (dd, $1 \mathrm{H}$,
$\mathrm{H}-7) ; 7.70$ (m, 2H, H-3 and H-5 pyridine); 6.82 (d, 1H, H-3). Anal. C, H, N.

\subsubsection{8-(Thien-2-yl)pyrazolo[5,1-c] $[1,2,4]$ benzotriazine 5-oxide (6)}

From 1, ${ }^{18}$ and 2-thiophen boronic acid, $3 \mathrm{~h}, 70^{\circ} \mathrm{C}$. Yellow crystals; TLC eluent: diisopropyl ether/cyclohexane 8:3 v/v; ${ }^{1} \mathrm{H}$ NMR $\left(\mathrm{CDCl}_{3}\right) \delta 8.59$ (d, $\left.1 \mathrm{H}, \mathrm{H}-9\right) ; 8.57$ (d, 2H, H-6); 8.14 (d, 1H, H-2); 7.87 (dd, 1H, H-7); 7.69 (d, 1H, H-5 thiophene); 7.57 (d, 1H, H-3 thiophene); 7.22 (m, 1H, H-4 thiophene); 6.79 (d, 1H, H-3). Anal. C, H, N.

\subsubsection{8-(Thien-3-yl)pyrazolo[ $[5,1-c][1,2,4]$ benzotriazine 5-oxide (7)}

From $1,{ }^{18}$ and 3-thiophen boronic acid, $1.5 \mathrm{~h}$, room temperature. Yellow crystals; TLC eluent: diisopropyl ether/cyclohexane $8: 3 \mathrm{v} / \mathrm{v} ;{ }^{1} \mathrm{H}$ NMR $\left(\mathrm{CDCl}_{3}\right) \delta 8.49(\mathrm{~m}, 2 \mathrm{H}, \mathrm{H}-6$ and $\mathrm{H}-9) ; 8.05(\mathrm{~d}$, $1 \mathrm{H}, \mathrm{H}-2) ; 7.78$ ( $\mathrm{m}, 2 \mathrm{H}, \mathrm{H}-7$ and $\mathrm{H}-2$ thiophene); $7.51(\mathrm{~m}, 1 \mathrm{H}, \mathrm{H}-4$ thiophene); 7.45 (m, 1H, H-5 thiophene); 6.69 (d, 1H, H-3). Anal. C, $\mathrm{H}, \mathrm{N}$.

\subsubsection{8-( $N$-Boc-pyrrol-2-yl)pyrazolo $[5,1-c][1,2,4]$ benzotriazine 5-oxide (9)}

From $1,{ }^{18}$ and $N($ Boc $)$ pyrrole-2-boronic acid $3 \mathrm{~h}, 60-70{ }^{\circ} \mathrm{C}$, in toluene. Red crystals; TLC eluent: toluene/ethyl acetate/acetic acid 8:2:1 v/v/v; ${ }^{1} \mathrm{H}$ NMR $\left(\mathrm{CDCl}_{3}\right) \delta 8.45(\mathrm{~m}, 2 \mathrm{H}, \mathrm{H}-6$ and $\mathrm{H}-9) ; 8.02(\mathrm{~d}$, $1 \mathrm{H}, \mathrm{H}-2) ; 7.73$ (dd, $1 \mathrm{H}, \mathrm{H}-7) ; 7.40$ (m, 1H, H-3 pyrrole); 6.65 (d, 1H, $\mathrm{H}-3) ; 6.50(\mathrm{~m}, 1 \mathrm{H}, \mathrm{H}-5$, pyrrole); $6.30(\mathrm{~m}, 1 \mathrm{H}, \mathrm{H}-4$ pyrrole); $1.40(\mathrm{~s}$, $\left.9 \mathrm{H},\left(\mathrm{CH}_{3}\right)_{3}\right)$. Anal. C, $\mathrm{H}, \mathrm{N}$.

\subsubsection{3-(Thien-3-yl)-8-phenylpyrazolo[5,1-c][1,2,4]- benzotriazine 5 -oxide (19)}

From 2, ${ }^{22}$ and phenylboronic acid, $8 \mathrm{~h}, 50-60{ }^{\circ} \mathrm{C}$. Red crystals; TLC eluent: diisopropyl ether/cyclohexane $8: 3 \mathrm{v} / \mathrm{v} ;{ }^{1} \mathrm{H}$ NMR $\left(\mathrm{CDCl}_{3}\right)$ $\delta 8.62$ (d, 1H, H-6); 8.59 (d, 1H, H-9); 8.36 (s, 1H, H-2); 7.93 (d, 1H, 
$\mathrm{H}-2$ thiophene); 7.88 (dd, $1 \mathrm{H}, \mathrm{H}-7) ; 7.80$ (d, 2H, H-2 and H-6 phenyl); 7.68 (d, 1H, H-4 thiophene); 7.55 ( $\mathrm{m}, 3 \mathrm{H}, \mathrm{H}-3, \mathrm{H}-4$ and $\mathrm{H}-5$ phenyl); 7.46 (m, 1H, H-5 thiophene). Anal. C, H, N.

\subsubsection{3-(Thien-3-yl)-8-(4-Methoxyphenyl)pyrazolo[5,1-}

\section{c] $[1,2,4]$-benzotriazine 5 -oxide (20)}

From $2{ }^{22}$ and 4-methoxyphenylboronic acid, $4 \mathrm{~h}, 60-70{ }^{\circ} \mathrm{C}$. Red crystals; TLC eluent: diisopropyl ether/cyclohexane $8: 3 \mathrm{v} / \mathrm{v} ;{ }^{1} \mathrm{H}$ NMR (DMSO- $\left.d_{6}\right) \delta 8.75(\mathrm{~s}, 1 \mathrm{H}, \mathrm{H}-2) ; 8.47(\mathrm{~m}, 2 \mathrm{H}, \mathrm{H}-6$ and $\mathrm{H}-9)$; 8.05 (dd, 1H, H-7); 8.00 (d, 1H, H-2 thiophene); 7.93 (d, 2H, H-2' and $\mathrm{H}^{-} 6^{\prime}$ phenyl); $7.79(\mathrm{~d}, 1 \mathrm{H}, \mathrm{H}-4$ thiophene); $7.72(\mathrm{~m}, 1 \mathrm{H}, \mathrm{H}-5$ thiophene); 7.15 (d, 2H, H-3' and $\mathrm{H}-5^{\prime}$ phenyl). Anal. C, H, N.

\subsubsection{3-(Thien-3-yl)-8-(thien-2-yl)pyrazolo[5,1-c] $[1,2,4]-$ benzotriazine 5 -oxide ( 21 )}

From 2, ${ }^{22}$ and 2-thiophenboronic acid, $2 \mathrm{~h}$, room temperature. Red crystals; TLC eluent: diisopropyl ether/cyclohexane $8: 3 \mathrm{v} / \mathrm{v}$; ${ }^{1} \mathrm{H}$ NMR $\left(\mathrm{CDCl}_{3}\right) \delta 8.58(\mathrm{~m}, 2 \mathrm{H}, \mathrm{H}-6$ and $\mathrm{H}-9) ; 8.36(\mathrm{~s}, 1 \mathrm{H}, \mathrm{H}-2)$; 7.93 (m, 1H, H-2, 3-thiophene); 7.85 (dd, 1H, H-7); 7.68 (m, 2H, $\mathrm{H}-4$, 3-thiophene and H-3, 8-thiophene); 7.58 (dd, 1H, H-5, 8-thiophene); 7.46 (dd, 1H, H-5, 3-thiophene); 7.21 (dd, 1H, H-4, 8-thiophene). Anal. C, H, N

\subsubsection{3-(Thien-3-yl)-8-(thien-3-yl)pyrazolo[5,1-c][1,2,4]-} benzotriazine 5 -oxide ( 22$)$

From $2,{ }^{22}$ and 3-thiophenboronic acid, $3 \mathrm{~h}, 80^{\circ} \mathrm{C}$, in toluene. Red crystals; TLC eluent: diisopropyl ether/cyclohexane $8: 3 \mathrm{v} / \mathrm{v} ;{ }^{1} \mathrm{H}$ NMR $\left(\mathrm{CDCl}_{3}\right) \delta 8.59$ (m, 2H, H-6 and H-9); 8.36 (s, 1H, H-2); 7.93 ( $\mathrm{m}, 1 \mathrm{H}, \mathrm{H}-2,3$-thiophene); 7.86 ( $\mathrm{m}, 2 \mathrm{H}, \mathrm{H}-7$ and $\mathrm{H}-2,8$-thiophene); 7.69 (dd, 1H, H-4, 3-thiophene); 7.61 (dd, 1H, H-4, 8-thiophene); 7.54 (dd, 1H, H-5, 8-thiophene); 7.46 (dd, 1H, H-5, 3-thiophene) Anal. C, H, N.

\subsubsection{3-(Thien-3-yl)-8-(N-Boc-pyrrol-2-yl)pyrazolo[5,1-c]- $[1,2,4]$ benzotriazine 5 -oxide $(24)$}

From $2,{ }^{22}$ and $N$ (Boc)pyrrole-2-boronic acid, $3 \mathrm{~h}, 60-70^{\circ} \mathrm{C}$, in toluene. Red crystals; TLC eluent: toluene/ethyl acetate/acetic acid $8: 2: 1 \mathrm{v} / \mathrm{v} / \mathrm{v} ;{ }^{1} \mathrm{H}$ NMR (DMSO- $\left.d_{6}\right) \delta 8.73(\mathrm{~s}, 1 \mathrm{H}, \mathrm{H}-2) ; 8.40(\mathrm{~d}, 1 \mathrm{H}, \mathrm{H}-$ 6), 8.21 (d, 1H, H-9); 7.99 (m, 1H, H-2, 3-thiophene); 7.75 (m, 3H, $\mathrm{H}-7$ and $\mathrm{H}-5$, 3-thiophene and $\mathrm{H}-3$ pyrrole); $7.57(\mathrm{~m}, 1 \mathrm{H}, \mathrm{H}-4,3-$ thiophene); $6.70(\mathrm{~m}, 1 \mathrm{H}, \mathrm{H}-5$, pyrrole); $6.51(\mathrm{~m}, 1 \mathrm{H}, \mathrm{H}-4$ pyrrole); $1.40\left(\mathrm{~s}, 9 \mathrm{H},\left(\mathrm{CH}_{3}\right)_{3}\right)$. Anal. $\mathrm{C}, \mathrm{H}, \mathrm{N}$

\subsubsection{3-(N-Boc-pyrrol-2-yl)-8-(thien-3-yl)pyrazolo[5,1-c] $[1,2,4]$ benzotriazine 5 -oxide (27)}

From 15 (see below) and $N$ (Boc)pyrrole-2-boronic acid, $3 \mathrm{~h}$, $60-70^{\circ} \mathrm{C}$, in toluene. Red crystals; TLC eluent: toluene/ethyl acetate/acetic acid 8:2:1 v/v/v; ${ }^{1} \mathrm{H}$ NMR $\left(\right.$ DMSO- $\left.d_{6}\right) \delta 8.51(\mathrm{~d}, 1 \mathrm{H}$ $\mathrm{H}-9$ ); 8.38 (m, 1H, H-2 thiophene); 8.36 (d, 1H, H-6); 8.32 (s, 1H, $\mathrm{H}-2) ; 8.18(\mathrm{dd}, 1 \mathrm{H}, \mathrm{H}-7) ; 7.80(\mathrm{~m}, 1 \mathrm{H}, \mathrm{H}-5$, thiophene); $7.70(\mathrm{~m}$ $1 \mathrm{H}, \mathrm{H}-4$ thiophene); $7.39(\mathrm{~m}, 1 \mathrm{H}, \mathrm{H}-3$ pyrrole); $6.40(\mathrm{~m}, 1 \mathrm{H}, \mathrm{H}-5$, pyrrole); $6.30\left(\mathrm{~m}, 1 \mathrm{H}, \mathrm{H}-4\right.$ pyrrole); $1.30\left(\mathrm{~s}, 9 \mathrm{H},\left(\mathrm{CH}_{3}\right)_{3}\right)$. Anal. $\mathrm{C}$, $\mathrm{H}, \mathrm{N}$.

\subsubsection{3-(2-Thienylmethoxycarbonyl)-8-(4-methoxy-}

\section{phenyl)pyrazolo[5,1-c][1,2,4]benzotriazine 5-oxide (32)}

From 31, ${ }^{22}$ and 4-methoxyphenylboronic acid, $8 \mathrm{~h}$, room temperature. Yellow crystals; TLC eluent: toluene/ethyl acetate $8: 3 \mathrm{v} /$ v; ${ }^{1} \mathrm{H}$ NMR $\left(\mathrm{CDCl}_{3}\right) \delta 8.68$ (s, 1H, H-2); 8.51 (d, 1H, H-9); 8.49 (d, $1 \mathrm{H}, \mathrm{H}-6) ; 8.12$ (dd, $1 \mathrm{H}, \mathrm{H}-7$ ); 7.95 (d, 2H, H-2 and $\mathrm{H}-6$ phenyl); $7.60(\mathrm{~d}, 1 \mathrm{H}, \mathrm{H}-5$ thiophene); $7.30(\mathrm{~d}, 1 \mathrm{H}, \mathrm{H}-3$ thiophene); 7.60 (d, $2 \mathrm{H}, \mathrm{H}-3$ and $\mathrm{H}-5$ phenyl); $7.08(\mathrm{~m}, 1 \mathrm{H}, \mathrm{H}-5$ thiophene); 5.52 (s, $\left.2 \mathrm{H}, \mathrm{CH}_{2}\right) ; 3.80\left(\mathrm{~s}, 3 \mathrm{H}, \mathrm{CH}_{3}\right)$. Anal. $\mathrm{C}, \mathrm{H}, \mathrm{N}$.
5.2.14. 3-(2-Thienylmethoxycarbonyl)-8-( $N$-Boc-pyrrol-2-yl)pyrazolo[5,1-c] $[1,2,4]$ benzotriazine 5 -oxide (33)

From 31,22 and $N$ (Boc)pyrrole-2-boronic acid, $3 \mathrm{~h}$, refluxing temperature, in toluene. Yellow crystals; TLC eluent: toluene/ethyl acetate/acetic acid 8:2:1 v/v/v; ${ }^{1} \mathrm{H}$ NMR (DMSO- $\left.d_{6}\right) \delta 8.67(\mathrm{~s}, 1 \mathrm{H}, \mathrm{H}-$ 2); 8.40 (d, 1H, H-6), 8.23 (d, 1H, H-9); 7.82 (dd, 1H, H-7); 7.60 (m, $1 \mathrm{H}, \mathrm{H}-5$ thiophene); 7.55 (m, $1 \mathrm{H}, \mathrm{H}-3$ pyrrole); $7.30(\mathrm{~m}, 1 \mathrm{H}, \mathrm{H}-3,3-$ thiophene); $7.01(\mathrm{~m}, 1 \mathrm{H}, \mathrm{H}-4$ thiophene); $6.71(\mathrm{~m}, 1 \mathrm{H}, \mathrm{H}-5$, pyrrole); $6.42\left(\mathrm{~m}, 1 \mathrm{H}, \mathrm{H}-4\right.$ pyrrole); $5.51\left(\mathrm{~s}, 2 \mathrm{H}, \mathrm{CH}_{2}\right) ; 1.40(\mathrm{~s}, 9 \mathrm{H}$, $\left.\left(\mathrm{CH}_{3}\right)_{3}\right)$. Anal. $\mathrm{C}, \mathrm{H}, \mathrm{N}$.

\subsubsection{3-(Fur-2-ylcarbonyl)-8-(4-methoxyphenyl)pyrazolo[5,1- c] $[1,2,4]$ benzotriazine 5 -oxide (35)}

From 30 (see below), and 4-methoxyphenylboronic acid, $12 \mathrm{~h}$ room temperature. Yellow crystals; TLC eluent: toluene/ethyl acetate $8: 3 \mathrm{v} / \mathrm{v} ;{ }^{1} \mathrm{H}$ NMR $\left(\mathrm{CDCl}_{3}\right) \delta 8.91(\mathrm{~s}, 1 \mathrm{H}, \mathrm{H}-2) ; 8.55(\mathrm{~d}, 1 \mathrm{H}, \mathrm{H}-9)$; 8.40 (d, 1H, H-6); 8.18 (m, 2H, H-7 and H-5 furane); 7.98 (d, 2H, H2 and $\mathrm{H}-6$ phenyl); 7.61 (d, 1H, H-3 furane); 7.18 (d, 2H, H-3 and $\mathrm{H}-$ 5 phenyl); $6.82\left(\mathrm{~m}, 1 \mathrm{H}, \mathrm{H}-4\right.$ furane); $3.80\left(\mathrm{~s}, 3 \mathrm{H}, \mathrm{CH}_{3}\right)$. Anal. $\mathrm{C}, \mathrm{H}, \mathrm{N}$.

\subsubsection{3-(Fur-2-ylcarbonyl)-8-( $N$-Boc-pyrrol-2-yl)pyrazolo[5,1-} c] $[1,2,4]$ benzotriazine 5 -oxide (36)

From 30 and $N$ (Boc)pyrrole-2-boronic acid, 3 h, refluxing temperature, in tetrahydrofurane. Yellow crystals; TLC eluent: toluene/ethyl acetate/acetic acid 8:2:1 v/v/v; ${ }^{1} \mathrm{H}$ NMR (DMSO- $\left.d_{6}\right) \delta$ 8.91 (s, 1H, H-2); 8.42 (d, 1H, H-6), 8.30 (d, 1H, H-9); 8.12 (d, $1 \mathrm{H}$ $\mathrm{H}-5$ furane); 7.82 (dd, $1 \mathrm{H}, \mathrm{H}-7) ; 7.62(\mathrm{~m}, 1 \mathrm{H}, \mathrm{H}-3$ furane); 7.58 (m, 1H, H-3 pyrrole); $6.82(\mathrm{~m}, 1 \mathrm{H}, \mathrm{H}-4$, furane); $6.72(\mathrm{~m}, 1 \mathrm{H}, \mathrm{H}-5$, pyrrole); 6.42 (m, 1H, H-4 pyrrole); $1.40\left(\mathrm{~s}, 9 \mathrm{H},\left(\mathrm{CH}_{3}\right)_{3}\right)$. Anal. C, $\mathrm{H}, \mathrm{N}$.

\subsection{3-(Fur-2-ylcarbonyl)-8-iodopyrazolo[5,1-c] $[1,2,4]$ - benzotriazine 5 -oxide $(30)$}

The starting material $\mathbf{2 9},{ }^{22}(0.22 \mathrm{mmol})$ was reacted with $2.5 \mathrm{~mL}$ of thionyl chloride and maintained at refluxing temperature for $1 \mathrm{~h}$. The final solution was evaporated in vacuo and the corresponding 3-carbonylchloride intermediate was utilized as that in the next Friedel-Craft reaction. Dichloromethane $(10 \mathrm{~mL}), \mathrm{SnCl}_{4}$ $(0.2 \mathrm{~mL})$, and furane $(0.2 \mathrm{~mL})$ were added to the carbonylchloride residue and the reaction was heated at $40-50{ }^{\circ} \mathrm{C}$, monitoring by TLC (eluent: toluene/ethyl acetate/acetic acid 8:2:1 v/v/v). The reaction was quenched with $\mathrm{HCl} 1: 1$, diluted with dichloromethane and the organic phase separated. The dichloromethane phase was washed with a saturated solution of sodium bicarbonate, dried over sodium sulfate anhydrous and evaporated. The final residue was purified by chromatography column (eluent: toluene/ethyl acetate/acetic acid 8:2:1 v/v/v) and $\mathbf{3 0}$ was eluted as the fast band. Yellow crystals; ${ }^{1} \mathrm{H}$ NMR (DMSO-d $\left.d_{6}\right) \delta 8.91(\mathrm{~s}, 1 \mathrm{H}, \mathrm{H}-2) ; 8.78(\mathrm{~d}, 1 \mathrm{H}$ $\mathrm{H}-9$ ); 8.18 (m, 3H, H-7, H-6 and H-5 furane); 7.61 (d, 1H, H-3 furane); $6.82(\mathrm{~m}, 1 \mathrm{H}, \mathrm{H}-4$ furane).

5.4. General procedure for the synthesis of derivatives $8,23,26$, and 39

A solution of potassium 2-furantrifluoroborate $(60 \mathrm{mg}$, $0.34 \mathrm{mmol}), \mathrm{PdCl}_{2}$ (dppf) $\mathrm{CH}_{2} \mathrm{Cl}_{2}(20 \mathrm{mg})$, triethylamine $(0.1 \mathrm{~mL})$ and the suitable starting materials: $1,{ }^{18} \mathbf{2}^{22}, \mathbf{1 5}, \mathbf{3 8},{ }^{22}(0.2 \mathrm{mmol})$ in $n$-propyl alcohol $(10 \mathrm{~mL})$ was stirred at reflux for $3 \mathrm{~h}$. The reaction was monitored by TLC (eluent: toluene/ethyl acetate/acetic acid 8:2:1 $\mathrm{v} / \mathrm{v} / \mathrm{v}$ ) and when the staring material disappeared, was cooled to room temperature, and diluted with water $(15 \mathrm{~mL})$. The appropriate work up of the final suspension gave the desired final products $8,23,26$, and 39 . 


\subsubsection{8-(Fur-2-yl)pyrazolo[5,1-c][1,2,4]benzotriazine 5-oxide}

(8)

From $1,{ }^{18}$ the final suspension was extracted with ethyl acetate and dried over sodium sulfate anhydrous. Evaporation of solution gave orange residue. ${ }^{1} \mathrm{H}$ NMR (DMSO- $\left.d_{6}\right) \delta 8.45(\mathrm{~m}, 2 \mathrm{H}, \mathrm{H}-6$ and H-9); 8.20 (d, 1H, H-2); 8.08 ( $\mathrm{m}, 2 \mathrm{H}, \mathrm{H}-7$ and $\mathrm{H}-5$ furane); 7.58 (m, 1H, H-3 furane); 6.92 (d, 1H, H-3); 6.80 (m, 1H, H-4 furane). Anal. C, H, N.

\subsubsection{3-(Thien-3-yl)-8-(fur-2-yl)pyrazolo[5,1-c][1,2,4]benzo- triazine 5-oxide (23)}

From 2,22 the final suspension was extracted with ethyl acetate $(10 \mathrm{~mL} \times 3)$, dried over sodium sulfate anhydrous and evaporated in vacuo and the residue recrystallized. Red crystals; ${ }^{1} \mathrm{H}$ NMR (DMSO- $\left.d_{6}\right) \delta 8.78(\mathrm{~s}, 1 \mathrm{H}, \mathrm{H}-2) ; 8.49(\mathrm{~m}, 2 \mathrm{H}, \mathrm{H}-6$ and $\mathrm{H}-9$ ); 8.08 (d, 1H, H-7); 8.02 (s, 1H, H-2, thiophene); 8.00 (d, $1 \mathrm{H}, \mathrm{H}-5$ furane); $7.77(\mathrm{~m}, 1 \mathrm{H}, \mathrm{H}-4$, thiophene); $7.72(\mathrm{~m}, 1 \mathrm{H}$, $\mathrm{H}-5$, thiophene); $7.58(\mathrm{~d}, 1 \mathrm{H}, \mathrm{H}-3$ furane $) ; 6.78(\mathrm{~m}, 1 \mathrm{H}, \mathrm{H}-4$ furane). Anal. $\mathrm{C}, \mathrm{H}, \mathrm{N}$.

\subsubsection{3-(Fur-2-yl)-8-(thien-3-yl)pyrazolo[5,1-c][1,2,4]benzo- triazine 5-oxide (26)}

From 15. The precipitate was filtered and purified by silica gel chromatography (eluting with toluene/ethyl acetate/acetic acid $8: 2: 1 \mathrm{v} / \mathrm{v} / \mathrm{v})$. Red crystals; ${ }^{1} \mathrm{H}$ NMR (DMSO- $\left.d_{6}\right) \delta 8.60(\mathrm{~s}, 1 \mathrm{H}, \mathrm{H}-2$ ); 8.58 (d, $1 \mathrm{H}, \mathrm{H}-9) ; 8.45$ ( $\mathrm{m}, 2 \mathrm{H}, \mathrm{H}-6$ and $\mathrm{H}-2$ thiophene); 8.12 (dd, $1 \mathrm{H}, \mathrm{H}-7) ; 7.88$ ( $\mathrm{m}, 1 \mathrm{H}, \mathrm{H}-5$, thiophene); 7.80 ( $\mathrm{m}, 2 \mathrm{H}, \mathrm{H}-4$ thiophene and $\mathrm{H}-5$ furane); 6.85 (d, $1 \mathrm{H}, \mathrm{H}-3$ furane); 6.68 ( $\mathrm{m}, 1 \mathrm{H}, \mathrm{H}-4$ furane). Anal. C, H, N.

\subsubsection{Ethyl 1-(2-nitro-5-(fur-2-yl)phenyl)-5-aminopyrazol-4- carboxylate (39)}

From 38, ${ }^{22}$ dark-yellow crystals; ${ }^{1} \mathrm{H}$ NMR $\left(\right.$ DMSO- $\left._{6}\right) \delta 8.21$ (d, $\left.1 \mathrm{H}, \mathrm{H}-3^{\prime}\right) ; 8.01\left(\mathrm{dd}, 1 \mathrm{H}, \mathrm{H}-4^{\prime}\right) ; 7.97\left(\mathrm{~d}, 1 \mathrm{H}, \mathrm{H}-6^{\prime}\right) ; 7.93$ (s, 1H, H-5 furane); $7.70(\mathrm{~s}, 1 \mathrm{H}, \mathrm{H}-3) ; 7.41(\mathrm{~d}, 1 \mathrm{H}, \mathrm{H}-3$ furane); $6.73(\mathrm{~m}, 1 \mathrm{H}$, H-4 furane); 6.57 (br s, $2 \mathrm{H}, \mathrm{NH}_{2}$, exch.); 4.22 (q, $2 \mathrm{H}, \mathrm{CH}_{2}$ ); 1.35 (t, $3 \mathrm{H}, \mathrm{CH}_{3}$ ). Anal. $\mathrm{C}, \mathrm{H}, \mathrm{N}$.

\subsection{General procedure for the synthesis of derivatives 10 and 12-17}

A solution of appropriate starting material 3-9 $(0.30 \mathrm{mmol})$ in acetonitrile $(10 \mathrm{~mL})$ was added of iodine $(0.18 \mathrm{mmol})$ and cerium ammonium nitrate (CAN, $0.18 \mathrm{mmol}$ ) and maintained at room temperature for $45 \mathrm{~min}$. The final red solution was evaporated under reduced pressure and the residue was washed with a $10 \%$ sodium hydroxide solution, the precipitate filtered and recrystallized by suitable solvent.

\subsubsection{3-Iodo-8-(2-methoxyphenyl)pyrazolo[5,1- c] $[1,2,4]$ benzotriazine 5 -oxide (10)}

From 3. Orange crystals; TLC eluent: toluene/ethyl acetate/acetic acid 8:2:1 v/v/v; ${ }^{1} \mathrm{H}$ NMR (DMSO- $\left.d_{6}\right) \delta 8.46$ (d, $\left.1 \mathrm{H}, \mathrm{H}-6\right) ; 8.41(\mathrm{~d}$, $1 \mathrm{H}, \mathrm{H}-9$ ); 8.34 (s, 1H, H-2); 7.87 (dd, 1H, H-7); 7.53 (m, 2H, H-4 and H-6 phenyl); 7.25 (d, 1H, H-3 phenyl); 7.16 (t, 1H, H-5 phenyl); $3.85\left(\mathrm{~s}, 3 \mathrm{H}, \mathrm{OCH}_{3}\right)$. Anal. $\mathrm{C}, \mathrm{H}, \mathrm{N}$.

\subsubsection{3-Iodo-8-(4-methoxyphenyl)pyrazolo $[5,1-c][1,2,4]$ benzo- triazine 5-oxide (12)}

From 4. Orange crystals; TLC eluent: toluene/ethyl acetate/acetic acid 8:2:1 v/v/v; ${ }^{1} \mathrm{H}$ NMR (DMSO- $\left.d_{6}\right) \delta 8.46(\mathrm{~m}, 2 \mathrm{H}, \mathrm{H}-2$ and $\mathrm{H}-$ 6); 8.40 (d, 1H, H-9); 8.05 (dd, 1H, H-7); 7.92 (d, 2H, H-2 and H-6 phenyl); 7.13 (d, 2H, H-3 and $\mathrm{H}-5$ phenyl); 3.85 (s, 3H, $\mathrm{OCH}_{3}$ ). Anal. C, $\mathrm{H}, \mathrm{N}$.

\subsubsection{3-Iodo-8-(4-pyridyl)pyrazolo[5,1-c] $[1,2,4]$ benzotriazine 5- oxide (13)}

From 5. Orange crystals; TLC eluent: toluene/ethyl acetate/acetic acid 8:2:1 v/v/v; ${ }^{1} \mathrm{H}$ NMR (DMSO- $\left.d_{6}\right) \delta 8.79(\mathrm{~d}, 2 \mathrm{H}, \mathrm{H}-2$ and $\mathrm{H}-6$ pyridine); 8.64 (d, 1H, H-9); 8.55 (d, 1H, H-6); 8.44 (s, 1H, H-2); 8.15 (dd, $1 \mathrm{H}, \mathrm{H}-7) ; 7.98$ ( $\mathrm{m}, 2 \mathrm{H}, \mathrm{H}-3$ and $\mathrm{H}-5$ pyridine). Anal. C, $\mathrm{H}, \mathrm{N}$.

\subsubsection{3-Iodo-8-(thien-2-yl)pyrazolo[ $[5,1-c][1,2,4]$ benzotriazine 5-oxide (14)}

From 6. Orange crystals; TLC eluent: diisopropyl ether/cyclohexane $8: 3 \mathrm{v} / \mathrm{v} ;{ }^{1} \mathrm{H}$ NMR $\left(\mathrm{CDCl}_{3}\right) \delta 8.58(\mathrm{~m}, 2 \mathrm{H}, \mathrm{H}-6$ and $\mathrm{H}-9)$; 8.14 (s, 1H, H-2); 7.88 (dd, 1H, H-7); 7.69 (d, 1H, H-5 thiophene); $7.57(\mathrm{~d}, 1 \mathrm{H}, \mathrm{H}-3$ thiophene); $7.22(\mathrm{~m}, 1 \mathrm{H}, \mathrm{H}-4$ thiophene). Anal. C, $\mathrm{H}, \mathrm{N}$.

\subsubsection{3-Iodo-8-(thien-3-yl)pyrazolo $[5,1-c][1,2,4]$ benzotriazine 5-oxide (15)}

From 7. Orange crystals; TLC eluent: diisopropyl ether/cyclohexane $8: 3 \mathrm{v} / \mathrm{v} ;{ }^{1} \mathrm{H}$ NMR $\left(\mathrm{CDCl}_{3}\right) \delta 8.57(\mathrm{~m}, 2 \mathrm{H}, \mathrm{H}-6$ and $\mathrm{H}-9)$; $8.14(\mathrm{~s}, 1 \mathrm{H}, \mathrm{H}-2) ; 7.88(\mathrm{~m}, 2 \mathrm{H}, \mathrm{H}-7$ and $\mathrm{H}-2$ thiophene); $7.59(\mathrm{~m}$, 1H, H-4 thiophene); 7.45 ( $\mathrm{m}, 1 \mathrm{H}, \mathrm{H}-5$ thiophene). Anal. C, H, N.

\subsubsection{3-Iodo-8-(Fur-2-yl)pyrazolo[5,1-c][1,2,4]benzotriazine 5- oxide (16)}

From 8. Orange crystals; TLC eluent: diisopropyl ether/cyclohexane $8: 3 \mathrm{v} / \mathrm{v} ;{ }^{1} \mathrm{H}$ NMR (DMSO- $\left.d_{6}\right) \delta 8.47(\mathrm{~m}, 3 \mathrm{H}, \mathrm{H}-6, \mathrm{H}-2$, and $\mathrm{H}-9$ ); 8.05 (dd, 1H, H-7); 7.98 (m, 1H, H-5 furane); 7.52 (m, 1H, $\mathrm{H}-3$ furane); 6.79 (m, 1H, H-4 furane). Anal. C, H, N.

\subsubsection{3-Iodo-8-( $N$-Boc-pyrrol-2-yl)pyrazolo[5,1-c] $[1,2,4]$ benzo- triazine 5-oxide (17)}

From 9. Orange crystals; TLC eluent: toluene/ethyl acetate/acetic acid 8:2:1 v/v/v; ${ }^{1} \mathrm{H}$ NMR (DMSO- $\left.d_{6}\right) \delta 8.44(\mathrm{~m}, 3 \mathrm{H}, \mathrm{H}-2, \mathrm{H}-6$ and $\mathrm{H}-9) ; 7.85$ (d, 1H, H-7); 7.79 (m, 1H, H-3 pyrrole); 6.72 (m, 1H, H-5, pyrrole); $6.42\left(\mathrm{~m}, 1 \mathrm{H}, \mathrm{H}-4\right.$ pyrrole); $1.40\left(\mathrm{~s}, 9 \mathrm{H},\left(\mathrm{CH}_{3}\right)_{3}\right)$. Anal. C, $\mathrm{H}, \mathrm{N}$.

\subsection{3-Iodo-8-(2-hydroxyphenyl)pyrazolo[ $[5,1-c][1,2,4]$ benzo- triazine 5-oxide (11)}

A solution of $10(0.24 \mathrm{mmol})$ in dichloromethane $(15 \mathrm{~mL})$ was reacted with $\mathrm{BBr}_{3}(0.3 \mathrm{~mL})$ at refluxing temperature until the starting material disappeared in TLC (eluent: toluene/ethyl acetate/acetic acid 8:2:1). Then the final solution was treated with a $10 \%$ sodium hydroxide solution and the organic layer eliminated. The aqueous phase, after acidification $(\mathrm{HCl} 1: 1)$ was extracted with ethyl acetate, dried and evaporated dryness obtained a yellow residue that was purified by recrystallization. ${ }^{1} \mathrm{H}$ NMR (DMSO- $\left.d_{6}\right) \delta$ 10.2 (br s, $1 \mathrm{H}, \mathrm{OH}$ ); 8.55 (d, 1H, H-9); 8.46 (d, 1H, H-6); 8.34 (s, $1 \mathrm{H}, \mathrm{H}-2) ; 7.95$ (dd, $1 \mathrm{H}, \mathrm{H}-7) ; 7.50$ (d, 1H, H-3 phenyl); 7.35 (t, 1H, H-5 phenyl); 7.01 (d, 1H, H-6 phenyl); 7.00 (t, 1H, H-4 phenyl). Anal. C, H, N.

\subsection{General procedure for the synthesis of derivatives $18,25,28$, 34 and 37}

To a mixture of starting material 17, 24, 27, 33, and 36 $(0.15 \mathrm{mmol})$ and anhydrous THF $(2 \mathrm{~mL})$ was added a solution of sodium methoxide in methanol ( $2 \mathrm{~mL}$ of a $0.43 \mathrm{M}$ solution). The mixture was allowed to stir $1 \mathrm{~h}$ at room temperature and then treated with water. The resulting suspension was worked up and the row product recrystallized by suitable solvent.

In case of starting material $\mathbf{3 3}$ a trans-esterification occurred and the final product was the 3-methyl ester derivative $\mathbf{3 4}$. 
5.7.1. 3-Iodo-8-(pyrrol-2-yl)pyrazolo[ $[5,1-c][1,2,4]$ benzotriazine 5-oxide (18)

From 17. Red crystals; TLC eluent: toluene/ethyl acetate/acetic acid 8:2:1 v/v/v; ${ }^{1} \mathrm{H}$ NMR (DMSO-d $\left.d_{6}\right) \delta 12.00$ (br s, $1 \mathrm{H}, \mathrm{NH}$, exch.); 8.43 (s, 1H, H-2); 8.40 (d, 1H, H-9); 8.25 (d, 1H, H-6); 8.00 (dd, 1H $\mathrm{H}-7) ; 7.10(\mathrm{~m}, 1 \mathrm{H}, \mathrm{H}-3$ pyrrole); $7.05(\mathrm{~m}, 1 \mathrm{H}, \mathrm{H}-5$, pyrrole); $6.30(\mathrm{~m}$, $1 \mathrm{H}, \mathrm{H}-4$ pyrrole). Anal. $\mathrm{C}, \mathrm{H}, \mathrm{N}$.

\subsubsection{3-(Thien-3-yl)-8-(pyrrol-2-yl)pyrazolo $[5,1-c][1,2,4]$ benzo-} triazine 5-oxide (25)

From 24. Red crystals; TLC eluent: toluene/ethyl acetate/acetic acid 8:2:1 v/v/v; ${ }^{1} \mathrm{H}$ NMR (DMSO-d $\left.d_{6}\right) \delta 12.00$ (br s, $1 \mathrm{H}, \mathrm{NH}$, exch.); 8.73 (s, $1 \mathrm{H}, \mathrm{H}-2) ; 8.50$ (d, $1 \mathrm{H}, \mathrm{H}-9) ; 8.35$ (d, $1 \mathrm{H}, \mathrm{H}-6) ; 8.00(\mathrm{~m}, 2 \mathrm{H}$ $\mathrm{H}-7$ and $\mathrm{H}-2,3$-thiophene); $7.78(\mathrm{~m}, 1 \mathrm{H}, \mathrm{H}-5,3$-thiophene); 7.70 ( $\mathrm{m}, 1 \mathrm{H}, \mathrm{H}-5,3$-thiophene); $7.12(\mathrm{~m}, 1 \mathrm{H}, \mathrm{H}-5$, pyrrole); $7.01(\mathrm{~m}$, $1 \mathrm{H}, \mathrm{H}-4$ pyrrole); 6.30 (m, 1H, H-3 pyrrole). Anal. C, $\mathrm{H}, \mathrm{N}$.

\subsubsection{3-(Pyrrol-2-yl)-8-(thien-3-yl)pyrazolo[5,1-c] $[1,2,4]$ benzo-} triazine 5-oxide (28)

From 27. Red crystals; TLC eluent: toluene/ethyl acetate/acetic acid 8:2:1 v/v/v; ${ }^{1} \mathrm{H}$ NMR (DMSO- $d_{6}$ ) $\delta 11.35$ (br s, $1 \mathrm{H}, \mathrm{NH}$, exch.); $8.51(\mathrm{~m}, 2 \mathrm{H}, \mathrm{H}-6$ and $\mathrm{H}-2) ; 8.42(\mathrm{~m}, 2 \mathrm{H}, \mathrm{H}-9$ and $\mathrm{H}-2$ thiophene); $8.01(\mathrm{dd}, 1 \mathrm{H}, \mathrm{H}-7) ; 7.83(\mathrm{~m}, 1 \mathrm{H}, \mathrm{H}-5$, thiophene); $7.70(\mathrm{~m}, 1 \mathrm{H}, \mathrm{H}-$ 4 thiophene); $6.90(\mathrm{~m}, 1 \mathrm{H}, \mathrm{H}-3$ pyrrole $) ; 6.60(\mathrm{~m}, 1 \mathrm{H}, \mathrm{H}-5$, pyrrole $)$ $6.18(\mathrm{~m}, 1 \mathrm{H}, \mathrm{H}-4$ pyrrole). Anal. $\mathrm{C}, \mathrm{H}, \mathrm{N}$.

\subsubsection{3-Methoxycarbonyl-8-(pyrrol-2-yl)pyrazolo[5,1-c][1,2,4]- benzotriazine 5 -oxide (34)}

From 33, in reaction conditions a trans-esterification occurred Red crystals; TLC eluent: toluene/ethyl acetate/acetic acid 8:2:1 $\mathrm{v} / \mathrm{v} / \mathrm{v} ;{ }^{1} \mathrm{H}$ NMR (DMSO- $d_{6}$ ) $\delta 12.1$ (br s, $1 \mathrm{H}, \mathrm{NH}$, exch.); 8.67 (s, $1 \mathrm{H}, \mathrm{H}-2$ ); 8.55 (d, 1H, H-9); 8.38 (d, 1H, H-6), 8.08 (dd, 1H, H-7); $7.18(\mathrm{~m}, 1 \mathrm{H}, \mathrm{H}-3$ pyrrole); 7.08 (m, 1H, H-5, pyrrole); $6.30(\mathrm{~m}$, $1 \mathrm{H}, \mathrm{H}-4$ pyrrole); $3.90\left(\mathrm{~s}, 3 \mathrm{H}, \mathrm{CH}_{3}\right)$. Anal. $\mathrm{C}, \mathrm{H}, \mathrm{N}$.

\subsubsection{3-(Fur-2-ylcarbonyl)-8-(pyrrol-2-yl)pyrazolo[5,1-c] $[1,2,4]$ - benzotriazine 5-oxide (37)}

From 36. TLC eluent: toluene/ethyl acetate/acetic acid 8:2:1 v/v/ v; ${ }^{1} \mathrm{H}$ NMR (DMSO-d ( $\left._{6}\right) \delta 12.00$ (br s, $1 \mathrm{H}, \mathrm{NH}$, exch.); $8.91(\mathrm{~s}, 1 \mathrm{H}, \mathrm{H}-$ 2); 8.60 (d, $1 \mathrm{H}, \mathrm{H}-9) ; 8.38$ (d, $1 \mathrm{H}, \mathrm{H}-6), 8.12(\mathrm{~m}, 2 \mathrm{H}, \mathrm{H}-7$ and $\mathrm{H}-5$ furane); 7.62 (m, $1 \mathrm{H}, \mathrm{H}-3$ furane); $7.15(\mathrm{~m}, 1 \mathrm{H}, \mathrm{H}-3$ pyrrole); 7.08 (m, 1H, H-5, pyrrole); 6.80 (m, 1H, H-4 furane); $6.30(\mathrm{~m}, 1 \mathrm{H}, \mathrm{H}-4$ pyrrole). Anal. C, H, N.

\subsection{3-Carboxy-8-(fur-2-yl)pyrazolo[5,1-c] $[1,2,4]$ benzotriazine 5-oxide (40)}

A solution of $39(0.5 \mathrm{mmol})$ in diglyme $(5 \mathrm{~mL})$ was added of $25 \mathrm{~mL}$ of $10 \%$ sodium hydroxide solution and was kept at 50 $60{ }^{\circ} \mathrm{C}$ until the starting material disappeared, monitoring by TLC. The final suspension was treated with hydrochloric acid and the filtration of the precipitate afforded to the acid derivative 40. The crude products were then recrystallized by suitable solvent. Yellow crystals; TLC eluent: toluene/ethyl acetate/acetic acid 8:2:1 v/v/v; ${ }^{1} \mathrm{H}$ NMR (DMSO-d $\left.d_{6}\right) \delta 12.9$ (br s, $1 \mathrm{H}, \mathrm{OH}$, exch.); 8.61 (s, $1 \mathrm{H}, \mathrm{H}-3$ ); 8.51 (d, 1H, H-9); 8.48 (d, 1H, H-6); 8.15 (dd, 1H, H-7); 8.03 (d, $1 \mathrm{H}, \mathrm{H}-5$ furane); 7.60 (d, $1 \mathrm{H}, \mathrm{H}-3$ furane); $6.80(\mathrm{~m}, 1 \mathrm{H}, \mathrm{H}-4$ furane). Anal. C, H, N.

\subsection{3-(2-Thienylmethoxycarbonyl)-8-(fur-2-yl)pyrazolo[5,1-c]- $[1,2,4]$ benzotriazine 5 -oxide (41)}

A suspension of the acid $\mathbf{4 0}(0.337 \mathrm{mmol})$ in anhydrous THF and triethyl amine $(1: 3.5)$ was maintained at $0{ }^{\circ} \mathrm{C}$ in ice bath for $30^{\prime}$. To the suspension was added $i$-butylchloroformate $(0.2 \mathrm{~mL})$ and maintained under stirring for $1 \mathrm{~h}$, from $0{ }^{\circ} \mathrm{C}$ to room temperature, to permit the anhydride to form. The 2-thiophen methanol was added in excess $(0.2 \mathrm{~mL})$ and the reaction was monitored by TLC (eluent: toluene/ethyl acetate 8:2). The final suspension was diluted with water and extracted with ethyl acetate which was in turn washed with sodium hydrogen carbonate and, after the normal work up, the residue was purified by chromatography column. Yellow crystals. ${ }^{1} \mathrm{H}$ NMR (DMSO- $\left.d_{6}\right) \delta 8.68(\mathrm{~s}, 1 \mathrm{H}, \mathrm{H}-2) ; 8.52(\mathrm{~d}, 1 \mathrm{H}$ H-9); 8.49 (d, 1H, H-6); 8.14 (dd, 1H, H-7); 8.03 (d, 1H, H-5 furane); $7.60(\mathrm{~m}, 2 \mathrm{H}, \mathrm{H}-5$ thiophene and $\mathrm{H}-3$ furane); $7.30(\mathrm{~m}, 1 \mathrm{H}, \mathrm{H}-3,3-$ thiophene); $7.06(\mathrm{~m}, 1 \mathrm{H}, \mathrm{H}-4$ thiophene); $6.80(\mathrm{~m}, 1 \mathrm{H}, \mathrm{H}-4$ furane); $5.55\left(\mathrm{~s}, 2 \mathrm{H}, \mathrm{CH}_{2}\right)$. Anal. $\mathrm{C}, \mathrm{H}, \mathrm{N}$.

\subsection{3-(Fur-2-ylcarbonyl)-8-(fur-2-yl)pyrazolo[5,1-c] $[1,2,4]-$ benzotriazine 5 -oxide $(42)$}

To a mixture of acid $\mathbf{4 0}(0.20 \mathrm{mmol})$ and trichloroacetonitrile $(0.60 \mathrm{mmol})$ in dichloromethane $(10 \mathrm{~mL})$ was added triphenylphosphine $(0.60 \mathrm{mmol})$ in dichloromethane $(1.0 \mathrm{~mL})$ dropwise at room temperature. The reaction mixture was stirred at room temperature for $2 \mathrm{~h}$ until the starting material disappeared in TLC (eluent: toluene/ethyl acetate/acetic acid 8:2:1 v/v/v). The reaction was then treated with $\mathrm{SnCl}_{4}(0.1 \mathrm{~mL})$ followed furane $(0.1 \mathrm{~mL})$ After $30^{\prime}$ the solution was treated with water and the organic layer was separated, dried and evaporated to dryness. The residue was recovered by diisopropyl ether and recrystallized by suitable solvent. Yellow crystals. TLC eluent: toluene/ethyl acetate/acetic acid $8: 2: 1 \mathrm{v} / \mathrm{v} / \mathrm{v} ;{ }^{1} \mathrm{H}$ NMR (DMSO-d $\left.{ }_{6}\right) \delta 8.91(\mathrm{~s}, 1 \mathrm{H}, \mathrm{H}-2) ; 8.58(\mathrm{~d}, 1 \mathrm{H}, \mathrm{H}-$ 9); 8.50 (d, 1H, H-6), 8.16 (dd, 1H, H-7); 8.12 (m, 1H, H-5, 2-furoyl); 8.06 ( $\mathrm{m}, 1 \mathrm{H}, \mathrm{H}-5$ furane); 7.62 ( $\mathrm{m}, 2 \mathrm{H}, \mathrm{H}-3,2$-furoyl and furane); $6.83(\mathrm{~m}, 2 \mathrm{H}, \mathrm{H}-4,2$-furoyl and furane). Anal. C, H, N.

\subsection{Radioligand binding assay}

$\left[{ }^{3} \mathrm{H}\right]$ Ro15-1788 (specific activity $78.8 \mathrm{Ci} / \mathrm{mmol}$ ) was obtained from Perkin-Elmer. ${ }^{30,31}$ All the other chemicals, which were of reagent grade, were obtained from commercial suppliers.

Bovine cerebral cortex membranes were prepared as previously described. The membrane preparations were diluted with $50 \mathrm{mM}$ Tris-citrate buffer $\mathrm{pH}$ 7.4, and used in the binding assay. Protein concentration was assayed using the method of Lowry et al. ${ }^{32}$ $\left[{ }^{3} \mathrm{H}\right]$ Ro $15-1788$ binding studies were performed as previously reported. ${ }^{20}$ At least six different concentrations of each compound were used. The data of $n=5$ experiments carried out in triplicate were analyzed by means of an iterative curve-fitting procedure (program Prism, GraphPad, San Diego, CA), which provided IC $_{50}$, $K_{\mathrm{i}}$, and SEM values for tested compounds, the $K_{\mathrm{i}}$ values being calculated from the Cheng and Prusoff equation. ${ }^{33}$

\section{Supplementary data}

Supplementary data associated with this article can be found, in the online version, at doi:10.1016/j.bmc.2011.04.009.

\section{References and notes}

1. D'Hulst, C.; Atack, J. R.; Kooy, R. F. Drug Discovery Today 2009, 14, 866.

2. Olsen, R. W. Sieghart W. Pharmacol Rev, 2008, 60, 243.

3. Collingridge, G. L.; Olsen, R. W.; Peters, J.; Spedding, M. Neuropharmacology 2009, 56, 2 .

4. Rudolph, U.; Mohler, H. Annu. Rev. Pharmacol. Toxicol. 2004, 44, 475.

5. Rudolph, U.; Mohler, H. Curr. Opin. Pharmacol. 2006, 6, 1.

6. Whiting, P. J. Curr. Opin. Pharmacol. 2006, 6, 24

7. McKernan, R. M.; Rosahl, T. W.; Reynolds, D. S.; Sur, C.; Wafford, K. A.; Atack, J. R.; Farrar, S.; Myers, J.; Cook, G.; Ferris, P.; Garrett, L.; Bristow, L.; Marshall, G.; Macaulay, A.; Brown, N.; Howell, O.; Moore, K. W.; Carling, R. W.; Street, L. J.; Castro, J. L.; Ragan, C. I.; Dawson, G. R.; Whiting, P. J. Nat. Neurosci. 2000, 3 587. 
8. Ebert, B.; Wafford, K. A.; Deacon, S. Pharmacol. Ther. 2006, 112, 612.

9. Savic, M. M.; Obradovic, D. I.; Ugresic, N. D.; Bokonjic, D. R. Neural Plast. 2005, $12,289$.

10. Löw, K.; Crestani, F.; Keist, R.; Benke, D.; Brünig, I.; Benson, J. A.; Fritschy, J. M.; Rülicke, T.; Bluethmann, H.; Möhler, H.; Rudolph, U. Science 2000, 290, 131.

11. Reynolds, D. S. Pharmacol. Biochem. Behav. 2008, 90, 37.

12. Yee, B. K.; Keist, R.; von Boehmer, L.; Studer, R.; Benke, D.; Hagenbuch, N.; Dong, Y.; Malenka, R. C.; Fritschy, J.-M.; Bluethmann, H.; Feldon, J.; Mohler, H.; Rudolph, U. Proc. Natl. Acad. Sci. U.S.A. 2005, 102, 17154.

13. Zhang, W.; Koehler, K. F.; Zhang, P.; Cook, J. M. Drug Des. Discov. 1995, 12, 193.

14. Clayton, T.; Chen, J. L.; Ernst, M.; Richter, L.; Cromer, B. A.; Morton, C. J.; Ng, H.; Kaczorowski, C. C.; Helmstetter, F. J.; Furtmuller, R.; Ecker, G.; Parker, M. W.; Sieghart, W.; Cook, J. M. Curr. Med. Chem. 2007, 14, 2755.

15. Ernst, M.; Bruckner, S.; Boresch, S.; Sieghart, W. Mol. Pharmacol. 2005, 68, 1291.

16. Guerrini, G.; Ciciani, G.; Cambi, G.; Bruni, F.; Selleri, S.; Guarino, C.; Melani, F.; Montali, M.; Martini, C.; Ghelardini, C.; Norcini, M.; Costanzo, A. J. Med. Chem. 2009, 52, 4668.

17. Costanzo, A.; Guerrini, G.; Ciciani, G.; Bruni, F.; Costagli, C.; Selleri, S.; Besnard, F.; Costa, B.; Martini, C.; Malmberg-Aiello, P. J. Med. Chem. 2002, 45, 5710.

18. Guerrini, G.; Ciciani, G.; Cambi, G.; Bruni, F.; Selleri, S.; Besnard, F.; Montali, M.; Martini, C.; Ghelardini, C.; Galeotti, N.; Costanzo, A. Bioorg. Med. Chem. 2007, $15,2573$.

19. Guerrini, G.; Ciciani, G.; Cambi, G.; Bruni, F.; Selleri, S.; Melani, F.; Montali, M.; Martini, C.; Ghelardini, C.; Norcini, M.; Costanzo, A. Bioorg. Med. Chem. 2008, 16, 4471.

20. Costanzo, A.; Guerrini, G.; Ciciani, G.; Bruni, F.; Selleri, S.; Costa, B.; Martini, C.; Lucacchini, A.; Malmberg-Aiello, P.; Ipponi, A. J. Med. Chem. 1999, 42, 2218.
21. Guerrini, G.; Costanzo, A.; Bruni, F.; Selleri, S.; Casilli, M. L.; Giusti, L.; Martini, C.; Lucacchini, A.; Malmberg Aiello, P.; Ipponi, A. Eur. J. Med. Chem. 1996, 31, 259.

22. Guerrini, G.; Costanzo, A.; Ciciani, G.; Bruni, F.; Selleri, S.; Costagli, C.; Besnard, F.; Costa, B.; Martini, C.; De Siena, G.; Malmberg-Aiello, P. Bioorg. Med. Chem. 2006, $14,758$.

23. Guerrini, G.; Ciciani, G.; Bruni, F.; Selleri, S.; Guarino, C.; Melani, F.; Montali, M.; Daniele, S.; Martini, C.; Ghelardini, C.; Norcini, M.; Ciattini, S.; Costanzo, A. J. Med. Chem. 2010, 53, 7532.

24. Molander, G. A.; Figueroa, R. Aldrichim. Acta 2005, 38, 49

25. Molander, G. A.; Riviero, M. R. Org. Lett. 2002, 4, 107.

26. Rodrìguez-Franco, M. I.; Dorronsoro, I.; Hernandez-Higueras, A. I.; Antequera, G. Tetrahedron Lett. 2001, 42, 863.

27. Hasan, I.; Marinelli, E. R.; Lin, L.-C. C.; Fowler, F. W.; Levy, A. B. J. Org. Chem. 1981, 46, 157 .

28. Costanzo, A.; Guerrini, G.; Bruni, F.; Selleri, S. J. Heterocycl. Chem. 1994, 31, 1369.

29. Jang, D. O.; Park, D. J.; Kim, J. Tetrahedron Lett. 1999, 40, 5323.

30. Martini, C.; Lucacchini, A.; Ronca, G.; Hrelia, S.; Rossi, C. A. J. Neurochem. 1982, $38,15$.

31. Primofiore, G.; Da Settimo, F.; Taliani, S.; Marini, A. M.; Novellino, E.; Greco, G.; Lavecchia, A.; Besnard, F.; Trincavelli, L.; Costa, B.; Martini, C. J. Med. Chem. 2001, 44, 2286.

32. Lowry, O. H.; Rosenbrough, N. J.; Farr, A.; Barnard, E. A.; Skolnick, P.; Olsen, R. W.; Möhler, H.; Sieghart, W.; Biggio, G.; Braestrup, C.; Bateson, A. N.; Langer, S. Z. L.; Randali, R. J. J. Biol. Chem. 1951, 193, 265.

33. Cheng, Y.; Prusoff, W. H. Biochem. Pharmacol. 1973, 22, 3099. 